\title{
Evolution of modern river systems: an assessment of 'landscape memory' in Indian river systems
}

\author{
${ }^{1}$ Discipline of Earth Sciences, Indian Institute of Technology Gandhinagar, Gujarat-382355, India \\ 2. Department of Earth Sciences, IIT Kanpur, Uttar Pradesh 208016 \\ 3. Department of Earth and Environmental Sciences, IISER Bhopal; *Corresponding author, Email: vjain@iitgn.ac.in
}

(Received : 31/10/2018; Revised accepted : 24/07/2019)

https://doi.org/10.18814/epiiugs/2020/020035

Every river basin is characterised by an evolutionary history, which may be analysed at different time scales. This study provides a geological and geomorphic history of different river basins of India at different time scales ranging from millions of years to millennial time scales. The river basins in India are divided into six different groups on the basis of different tectono-climatic settings and geomorphic characteristics. The evolutionary trajectories in the past strongly govern the modern day geomorphic characteristics and processes in a river basin. The basin scale data compiled in this paper highlights the role of geological inheritance and 'landscape memory' in the evolution of river systems of India.

\section{Introduction}

Tectonic processes, climatic perturbations, and their interactions at long time scales exert primary controls on the trajectory of landscape evolution, which defines the physical appearance of a landscape (Bishop, 2007). Brierley (2010) further highlighted the inherent controls of landscape characteristics on present-day river morphology and processes and defined 'landscape memory' on river systems. Landscape memory was further divided into geological, climatic and anthropogenic memory, which strongly controls the appearance and behaviours of modern riverscapes (Brierley, 2010). Geological memory was referred to in the context of inherent properties such as lithology, presence of faults and lineaments, and tectonic forcings. Such geological controls are inherited in the landscape and determine its topographic characteristics such as elevation, slope and relief, and rock erodibility (Brierley, 2010). Geological characteristics and history of a region also defines the shape of a river basin, which further influences water and sediment fluxes in the channel (Tandon and Sinha, 2007). Further, climatic conditions in a river basin were defined as 'climatic memory'in river systems, which directly and indirectly controls the flux variability in river systems (Brierley, 2010). Therefore, the geomorphic characteristics of a river basin in any region are linked to the evolutionary history of the region and the contemporary basin physiography bears the imprints of the past river processes. Such parameters serve as boundary conditions within which the present day landscape-forming processes operate (Brierley and Fryirs, 2005). The elevation and relief of a region influence the orographic precipitation and also determine the potential energy of water flowing downslope. The coupled effect of climate and tectonics is crucial for the long-term sustenance of river basins. While uplift creates relief, runoff and discharge facilitate erosion for the maintenance of hill and channel slope (for water and sediment transfer). Lithology and inherent structural discontinuities dictate the sediment availability, and the prevailing climatic conditions determine the sediment transport and redistribution rates.

The topographic characteristics of the river basins in India display a wide range of tectono-climatic settings and therefore the deep rooted imprints of geological and climatic memory. Each landscape has its own unique history of evolutionary events. While tectonic uplift rate has exerted primary control on the formation of high elevation mountain ranges in the Himalaya, the peninsular region of India is characterised by relatively lower topography owing to the absence or insignificant level of active tectonic events in the recent past. The imprints of past geological processes are very prominent among the river basins in Peninsular India as many of them have their main channels developed along rift basins and lineaments which were active during the Proterozoic and reactivated in later phases of rifting of Pangea.

The significance of the age of relief formation on the drainage characteristics is evident among the coastal rivers. The escarpments along the western coast are higher than those along the eastern coast of India owing to the differences in geological history and evolution. Hence, rivers along the western coast differ in behaviour geomorphologically compared to the eastern coast rivers. This exemplifies the importance of landscape memory on river processes.

Here we present a review to understand the evolutionary trajectories of river basins in India at time scales ranging from millions of years to millennia. This work also assesses the controls of past geological processes on present-day river basin morphology and appearance of the major river basins in India. Based on the similarity and differences in geomorphic characteristics, a classification of the major river basin types has been made. The roles of past processes on the modern day system were analysed for these different classes of river systems. This approach is not only useful to comprehend the 
inherent controls on diversity in process-form relationships in different river basins of India, but also helps to understand evolutionary trajectory of a river system.

\section{Major River basins of India}

Indian rivers have been divided into 25 river basins comprising of major and minor river basins (Water Resource Information System, India) (Fig. 1). These river basins are markedly different in terms of hydrological and basin scale physical characteristics. We have further grouped these river basins on the basis of their geological evolution, climatic and sediment transport characteristics in the diverse tectonoclimatic settings (Table 1). The rivers of the Indian sub-continent has been classified into six major types, namely (I) Antecedent large Himalayan rivers; (II) Himalayan foothills-fed rivers; (III) North flowing cratonic rivers; (IV) West flowing peninsular rivers; (V) East flowing peninsular rivers; (VI) Coastal rivers along the Western Ghats Escarpment.

\section{Antecedent large Himalayan rivers}

The antecedent large Himalayan rivers originate from continental

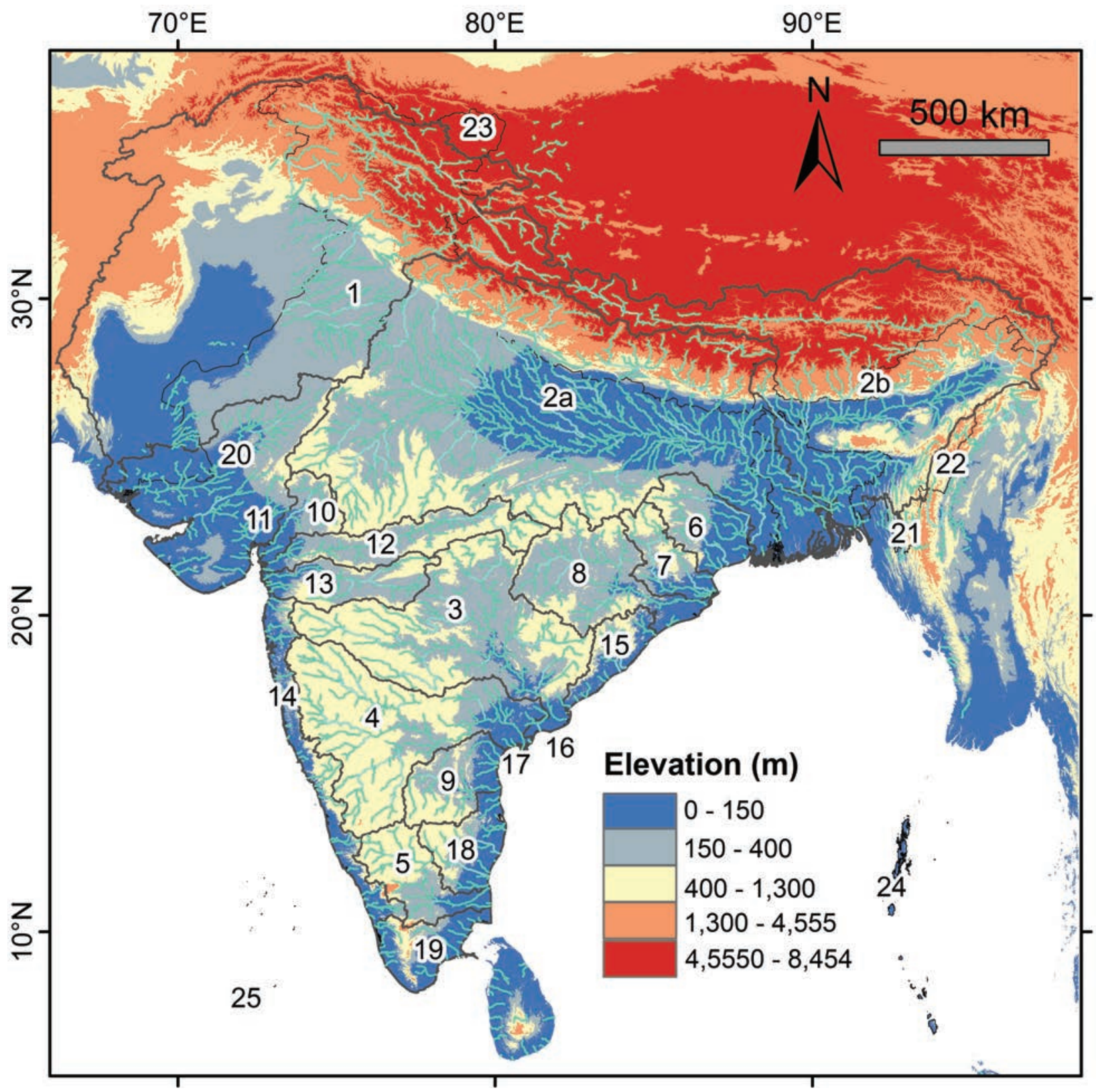

Figure 1. River basin boundaries of the major river basins in India superposed on SRTM DEM. (1-Indus up to border, 2 a-b-Ganga and Brahmaputra, 3-Godavari, 4-Krishna, 5-Cauvery, 6-Subarnrekha, 7-Brahmani-Baitrni, 8-Mahanadi, 9- Pennar, 10-Mahi, 11-Sabarmati, 12-Narmada, 13-Tapi, 14-West flowing coastal rivers, 15- East flowing rivers between Mahanadi and Godavari, 16- East flowing rivers between Krishna and Godavari, 17- East flowing rivers between Krishna and Pennar, 18-East flowing rivers between Pennar and Cauvery, 19- East flowing rivers from Tadri to Kanyakumari, 20- West flowing rivers of Kutch and Saurashtra including Luni, 21- Minor rivers draining into Bangladesh, 22- Minor rivers draining into Myanmar, 23-Area of North Ladakh not draining into Indus Basin, 24- Drainage area of Andaman \& Nicobar Islands, 25- Drainage area of Lakshadweep Islands) 
Table 1. Physiographic characteristics of the major river basins (source: Sonam and Jain, 2018; WRIS Report, 2014)

\begin{tabular}{|c|c|c|c|c|c|}
\hline River basin type & $\begin{array}{l}\text { River basin } \\
\text { name }\end{array}$ & $\begin{array}{l}\text { Total length } \\
\qquad(\mathrm{km})\end{array}$ & $\begin{array}{c}\text { Basin area } \\
\left(\mathrm{km}^{2}\right)\end{array}$ & $\begin{array}{c}\text { Relief } \\
(\mathrm{m})\end{array}$ & Lithology \\
\hline & Bhagirathi & 177 & 6921 & 4432 & $\begin{array}{l}\text { Medium to high grade metamorphic rocks of } \\
\text { the Higher and Lesser Himalayas }\end{array}$ \\
\hline & Alaknanda & 159 & 10882 & 4519 & $\begin{array}{l}\text { Medium to high grade metamorphic rocks of } \\
\text { the Higher and Lesser Himalayas }\end{array}$ \\
\hline & $\begin{array}{l}\text { Ganga (along } \\
\text { the Bhagirathi } \\
\text { River and up } \\
\text { to Farakka) }\end{array}$ & 2284 & 908828 & 4992 & $\begin{array}{l}\text { Medium to high grade metamorphic rocks of } \\
\text { the Higher and Lesser Himalayas, Alluvium }\end{array}$ \\
\hline \multirow[t]{4}{*}{ Antecedent large Himalayan rivers } & Yamuna & 1376 & 331030 & 2183 & $\begin{array}{l}\text { Medium to high grade metamorphic rocks of } \\
\text { the Higher and Lesser Himalayas, Alluvium }\end{array}$ \\
\hline & Ghaghra & 1183 & 131883 & 4587 & $\begin{array}{l}\text { Sediments of the Tethys Himalaya and Siwaliks, } \\
\text { and medium to high grade metamorphic rocks of } \\
\text { the Lesser and Higher Himalaya, Alluvium }\end{array}$ \\
\hline & Gandak & 778 & 42464 & 5392 & $\begin{array}{l}\text { Sediments of the Tethys Himalaya and Siwaliks, } \\
\text { and medium to high grade metamorphic rocks of } \\
\text { the Lesser and Higher Himalaya, Alluvium }\end{array}$ \\
\hline & Arun-Kosi & 736 & 60164 & 8019 & $\begin{array}{l}\text { Sediments of the Tethys Himalaya and Siwaliks, } \\
\text { and medium to high grade metamorphic rocks of } \\
\text { the Lesser and Higher Himalaya, Alluvium }\end{array}$ \\
\hline \multirow[t]{4}{*}{ Himalayan foothills-fed rivers } & Rapti & 642 & 14691 & 1735 & $\begin{array}{l}\text { Medium grade metamorphic rocks of the Lesser } \\
\text { Himalaya and Siwalik sediments }\end{array}$ \\
\hline & Ramganga & 566 & 22471 & 1968 & $\begin{array}{l}\text { Medium grade metamorphic rocks of the Lesser } \\
\text { Himalaya and Siwalik sediments, Alluvium }\end{array}$ \\
\hline & Baghmati & 470 & 3720 & 1709 & Sandstones, Alluvium \\
\hline & Kamla balan & 369 & 2980 & 589 & Sandstones, Alluvium \\
\hline \multirow[t]{4}{*}{ North flowing cratonic rivers } & Chambal & 960 & 143219 & 234 & Quartz arenite, sandstones \\
\hline & Betwa & 590 & 46580 & 364 & Quartz arenite, sandstones \\
\hline & Ken & 427 & 28058 & 350 & Quartz arenite, sandstones \\
\hline & Son & 881 & 70055 & 500 & Quartz arenite, sandstones \\
\hline \multirow[t]{2}{*}{ West flowing Peninsular rivers } & Narmada & 1312 & 98796 & 900 & Basalts, Granitic-gneisses, alluvium \\
\hline & Tapi & 724 & 65145 & 752 & Basalts, Granitic-gneisses, alluvium \\
\hline \multirow[t]{3}{*}{ East flowing Peninsular rivers } & Godavari & 1465 & 312812 & 1067 & $\begin{array}{l}\text { Basalts, medium to high grade metamorphic rocks } \\
\text { like (Schists and Granitic-gneisses), alluvium }\end{array}$ \\
\hline & Krishna & 1400 & 258948 & 1337 & $\begin{array}{l}\text { Basalts, medium to high grade metamorphic rocks } \\
\text { like (Schists and Granitic-gneisses), alluvium }\end{array}$ \\
\hline & Cauvery & 800 & 81155 & 1341 & $\begin{array}{l}\text { Granitic-gneisses, high grade metamorphic rocks } \\
\text { like charnokites, khondalites, and alluvium. }\end{array}$ \\
\hline $\begin{array}{l}\text { Coastal riversalong the Western } \\
\text { Ghat Escarpment }\end{array}$ & $\begin{array}{l}\text { Many } \\
\text { Independent } \\
\text { rivers flowing }\end{array}$ & - & 55940 & $\max 2500$ & $\begin{array}{l}\text { Basalts in northern part and high grade } \\
\text { metamorphic rocks in southern part }\end{array}$ \\
\hline
\end{tabular}

collision belts, with their trunk streams mostly transverse to the growing mountain range (Gupta, 1997; Tandon and Sinha, 2007) (Fig. 2). The average topographic characteristics of the antecedent rivers of the Ganga basin exhibit three distinct zones: (a) the northern most part of these large antecedent river basins comprise of low relief but high elevation $(\sim 5,000 \mathrm{~m})$ part of the Tibetan Plateau north of the Indus-Tsangpo suture zone, (b) the high relief and highly rugged Higher Himalaya region (bounded by the South Tibet Detachment Zone (STDZ) in the north and Main Central Thrust (MCT) in the south), (c) lower relief terrain of the Lesser Himalaya (bounded by the MCT in the north and Main Boundary Thrust (MBT) in the south) and the Siwaliks (bounded by the MBT in the north and Main Frontal Thrust (MFT) in the south). Large part of higher elevated Higher
Himalayan region is also characterised by vast glacier cover. Hinterland tectonic uplift of the Himalaya together with the monsoon precipitation has played the key role in sustenance of such large river basins and the transportation of huge amounts of water and sediment. Sinha and Friend (1994) defined these river systems as mountain-fed rivers, which are characterised by large basin area and multi-channel drainage systems with very high discharge and sediment load.

Within the hinterland area (upstream of mountain front), the large Himalayan antecedent rivers are characterised by incised bedrock channels. These rivers are characterised by high stream power values varying from $\sim 10,000$ to $1,30,000 \mathrm{~W} / \mathrm{m}$ (Fig. 2b-e) (Sonam and Jain, 2018) and consequently high denudation rates in the range of 0.5 to $2.4 \mathrm{~mm} / \mathrm{yr}$ (Lupker et al, 2012). The Ganga and Yamuna rivers within 

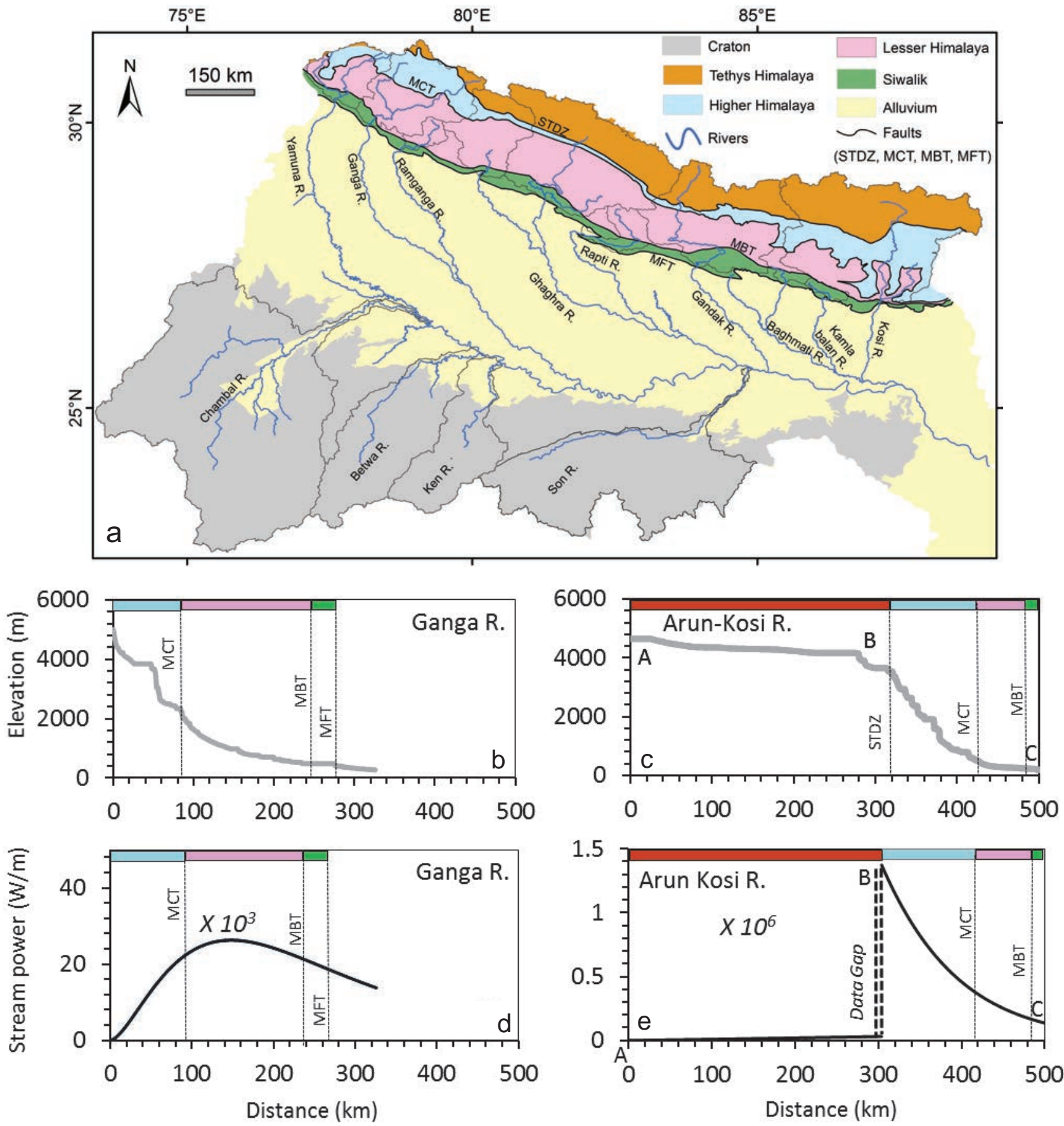

Figure 2. (a) Geological map of the Ganga River basin (modified from Sonam and Jain, 2018). (b-c) Longitudinal profiles of the Ganga and the Arun (Kosi basin) Rivers; (d-e) Stream power distribution along river long profile of Ganga and Arun (Kosi basin) rivers

the western Ganga plain (WGP), are braided channels with a narrow incised valley (Sinha et al., 2005a). There are cliffs up to 15 to $30 \mathrm{~m}$ above the modern channel of different rivers draining the WGP (Gibling et al, 2005; Shukla et al., 2012). In contrast, the Kosi and Gandak rivers in the eastern Ganga plains (EGP) are both characterised by high relief and high precipitation. The Kosi and Gandak rivers are characterised by high annual discharges $\left(2256\right.$ and $1,555 \mathrm{~m}^{3} / \mathrm{s}$ respectively) and high modern sediment loads ( 43 and $82 \mathrm{Mt} / \mathrm{yr})$ close to their mouths (Jain and Sinha, 2003a; Sinha et al., 2005a; Sinha et al., 2019). Consequently, large alluvial fans have developed at the mountain exit of the Gandak and Kosi rivers as they enter the plains because of low topographic gradients and longitudinal slopes.

\section{Himalayan foothills-fed rivers}

Foothills-fed rivers originate in the Lesser Himalaya or in the Siwaliks (Sinha and Friend, 1994). The Ramganga, Rapti, Baghmati, and Kamla-Balan (mixed-fed) rivers lie in this category (Fig. 2a). Unlike the large antecedent Himalayan rivers, the foothills-fed rivers have a larger percentage of their total basin area in the alluvial plains and have a number of plains-fed tributaries feeding its main channel. These are mostly sinuous single thread channels, though the upstream part near the mountain front shows braided pattern (Sinha and Friend, 1994; Jain and Sinha, 2003a). Although the smaller foothills-fed rivers do not have large catchments, or high relief in their hinterland, they 
do receive high sediment supply from the Siwaliks and experience intense flooding during the monsoon period. These floods form extensive overbank spreads of mud alluvium in the interfan areas (Sinha and Friend, 1994; Jain and Sinha, 2004). Active tectonics along subsurface faults in the alluvial plains area has also played an important role in controlling the present day river morphology and processes via changes in channel bed slope (Jain and Sinha, 2005).

Generally, planform morphology of foothills-fed rivers is meandering with braided nature only for reaches near the mountain exit. The channel cross-section width is narrow $(112-240 \mathrm{~m})$ with low width-depth ratio (Jain and Sinha, 2003a). Channel sinuosity is as high as 1.8 in some reaches of the Baghmati river (Jain and Sinha, 2005). These rivers have high suspended sediment concentration and low discharge (300 to 2500 cumecs). The sub-surface sedimentary sequence generated by the foothills-fed rivers therefore consists of thick mud deposits and narrow sand ribbons (Jain and Sinha, 2003a). Presence of several abandoned channels and oxbow lakes indicate frequently shifting nature of these channels.

\section{North flowing cratonic rivers}

Cratonic rivers of the Ganga river basin namely Chambal, Betwa, Ken and Son rivers originate in tectonically inactive low-relief mountain ranges and flows through semi-arid regions (Fig. 3). The Aravalli-Delhi Ridge in the west, the Rajmahal Hills in the east and the Bundelkhand-Vindhyan Plateau in the south define the hinterlands for the cratonic rivers draining through different parts of India. These are incised river systems that show diverse geomorphic features in response to climate and tectonic events (Sinha et al., 2009; Sahu et al., 2010; Ranga et al., 2016). The Chambal, Betwa, Ken and Son rivers are examples of these rivers. These river catchments have a relief of $\sim 500 \mathrm{~m}$ and the channels are incised with $\sim 20-35 \mathrm{~m}$ high cliffs. These rivers are fairly active in monsoon season when they receive $>85 \%$ of discharge (Sinha et al., 2009).

The cratonic rivers are characterised by largely bedrock reaches and incised valleys with steep walls (Gopal, 2016). The river long profiles show prominent convex zones along the physiographic transition zone from the Vindhyan and Malwa Plateau regions to the Ganga alluvial plains. The Son River is braided in the Ganga plains (Sahu et al., 2010). The denudation rates for the cratonic tributaries of the Ganga river are much lower than its Himalayan tributaries with values $\sim 0.007 \mathrm{~mm} / \mathrm{yr}$ (Lupker et al., 2012). However, the absence of major engineering structures across these river channels are responsible for high sediment supply at their confluences with the Himalayan axial rivers (Bawa et al., 2014).

\section{West flowing Peninsular rivers}

Among the major rivers in Peninsular India, the Narmada and Tapi Rivers are the two largest rivers with a westward flow draining into the Arabian Sea (Fig. 4). Developed within a rift-graben setting these rivers have typical elongated shape controlled by rift valleys (Tandon and Sinha, 2007). The initiation of rifting marked the onset of river valley formation and subsequent head ward erosion led to valley development. The dominant rock types include the Cretaceous Deccan basalts along with small parts comprising Archean granitic gneiss basement and alluvial deposits in the downstream coastal part. Owing to their development in a structurally controlled rift and graben setting, these rivers flow dominantly as a single channel with low sinuosity in a bedrock setting. Distinctive geomorphic features (boulder berms and highly incised channels) provide evidence of large floods, high flow velocities and elevated stream power per unit area in recent times with in the Narmada and Tapi River basins that has been attributed to climate change (Kale et al., 1994; Kale, 2007). Throughout their length, the incised channels exhibit patches of depositional point bars enclosed between high rocky banks.

The estimates of hydraulic parameters for large floods in the Narmada and Tapi Rivers in central India indicate that narrow bedrock reaches are associated with high values of specific stream power in the range of $10^{2}$ to $10^{3} \mathrm{Wm}^{-2}$ (Kale, 1994). River flows in nearly straight channel in the upstream and mid-stream reaches. The downstream reaches are characterised by incised meanders. Channel

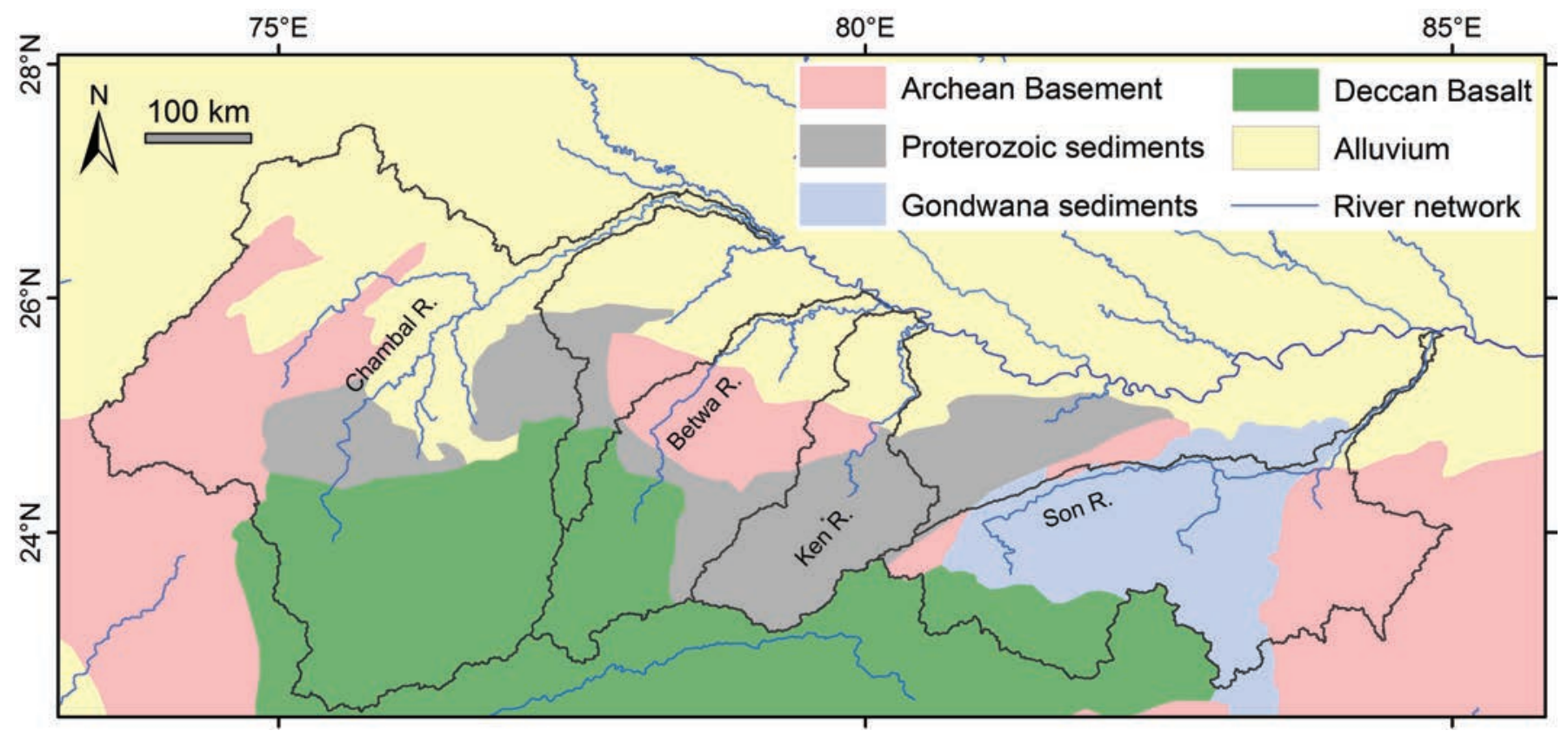

Figure 3. Geological map of the southern Ganga basin drained by cratonic tributaries (Geological units are from Narula et al., 2000). 
slopes are mostly $\sim 0.0008$ to $0.001 \mathrm{~m} / \mathrm{m}$ (Kale et al., 1994). Channel plan form morphology comprises pools and riffles in the upstream reaches and elongated point bars in the mid-stream and downstream reaches. These rivers have a typical box shaped channel cross section with width-depth ratios of $\sim 11$ and 59 , which implies a rapid increase in flow velocity and specific stream power during high monsoon flows (Kale et al., 1994).

\section{East flowing Peninsular rivers}

The landmass south of the Narmada-Tapi Rift is the broadly eastward tilting Indian Peninsula. The physiography of Peninsular

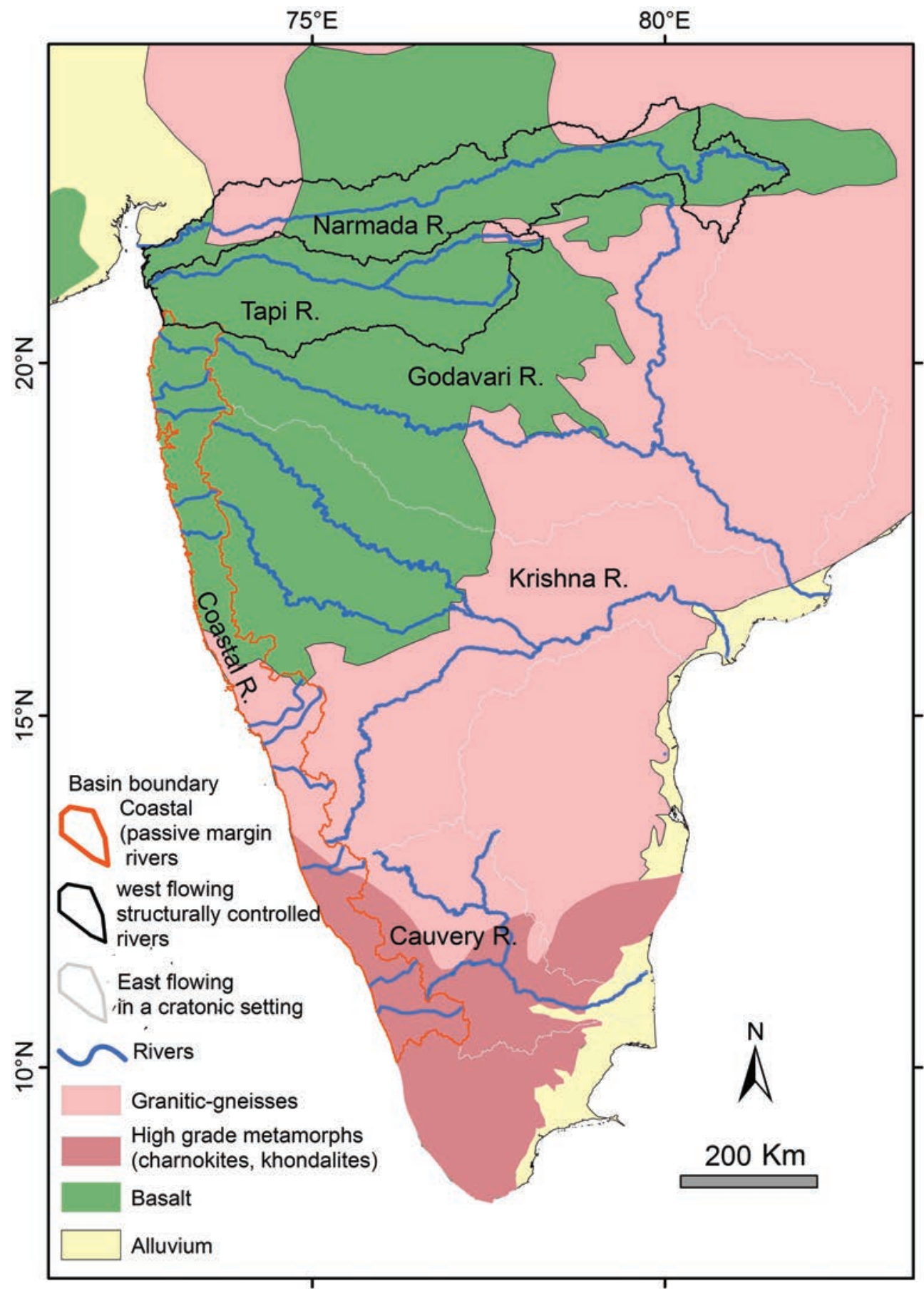

Figure 4. Geological map of the Indian Peninsula drained by the west flowing rivers, the coastal rivers and the east flowing rivers.
India is characterised by predominantly eastward flowing drainage (Fig. 4), with little role of active tectonics in present day drainage; notwithstanding that the regional physiography of this area was affected by tectonics at million years time scale, and the regional tilt in the last $25 \mathrm{Ma}$ grew at rates of up to $0.1 \mathrm{~mm} / \mathrm{yr}$ (Richards et al., 2016). The major rivers among the east flowing rivers of Peninsular India include the Krishna, Godavari and the Cauvery rivers. The initiation of these rivers has been attributed to the extensional rifting of Gondwana Land during the Early Jurassic / Late Cretaceous (Kale, 2014). The Archean and Precambrian crystalline rocks occupy nearly $80 \%$ of the basin, while the remaining $20 \%$ comprises Tertiary Deccan Traps and recent sediments (Ramesh and Subramanian, 1988;Babu and Lakshmi, 2005). The Cauvery River basin drains some of the oldest continental rocks of ArcheanProterozoic age. Its upstream area lies in the elevated Mysore Plateau. The Cauvery River and its tributaries have major knick points along the topographic transition zones from plateau to plains, which are marked as waterfalls (Kale, et al., 2014). Incised valleys in the middle reaches of the Cauvery River and formation of hanging valleys among its tributaries in response to incision of the main channel were attributed to Quaternary tectonics (Kale et al., 2014). The Godavari and Krishna rivers have originated in the high elevation (700 to $1400 \mathrm{~m}$ ) and high rainfall zone of the Western Ghats (Kale and Rajaguru, 1987). These rivers flow eastwards into broad valleys in the semi-arid eastern part. The Cauvery River flows through the semi-arid part towards the south of peninsular India. The major rock types include gneisses, charnockites and granitic rocks of Archean age (Sharma and Rajamani, 2001). The initiation of the Cauvery River Basin along the eastern passive margin of India and consequent sedimentation are attributed to the fragmentation of Eastern Gondwana and opening up of the Indian Ocean which began in the Late Jurassic ( 160 Ma ago) (Nagendra and Reddy, 2017).

The east flowing peninsular rivers flow in highly incised bedrock channels with low width-depth ratios, very low channel gradients and resistant channel boundaries in their upstream reaches (Gupta, 1988; Kale, 1998). River plan form morphology in the downstream alluvial reaches comprises wide ( 1000 m) channels with large sandy point bars as well 
as mid- channel bars. These rivers have adequate channel capacity to accommodate large flows.

\section{Coastal rivers along the Western Ghat Escarpment (WGE)}

The western margin of Peninsular India, also known as the Western Ghat Escarpment is a narrow belt of land about 10-25 km wide, bordering the Arabian Sea. There is a large number of rivers on the Western Coast - i.e. coastal Maharashtra and Karnataka, and all of Kerala (Fig. 4). These rivers are small in length but carry a significant amount of water owing to very high rainfall (with an annual average of $\sim 3000 \mathrm{~mm}$ ) in the Western Ghats. While they drain only $3 \%$ of India's land area, they carry $\sim 11 \%$ of India's water resources (WRIS Report, 2014). Climate has a dominant control on water resource availability in the region, which is characterised by more than 100 rainy days $(2.5 \mathrm{~mm} /$ day rainfall) in a year (Jain et al., 2007). These rivers drain across a passive margin escarpment known as the Western Ghats comprising Cretaceous Deccan basalts in its northern and central part and high grade metamorphic rocks in the south. This highly rugged region with a relief of $\sim 1 \mathrm{~km}$ has several small rivers carving deep gorges, spectacular waterfalls, referred to as knick points, and flowing in to the Arabian Sea.

West flowing rivers in the Western Ghat escarpment are generally incised bedrock rivers. The upstream segments of the channels, in the northern part, are generally moderately incised. On the contrary, the channels in the middle section of the escarpment between $\sim 14^{\circ}$ $16^{\circ} \mathrm{N}$ are highly incised (Guha and Jain, 2017). The valleys sometimes attain $\sim 150$ m deep gorges with 20 - 40 m wide channels. The upstream parts of the rivers are generally sediment starved with angular fragments. In general, the normalized channel steepness increases from north to south. Basin average erosion rate suggests that bedrock erosion rates are highest in the northern parts $\left(129.85 \pm 26.19 \mathrm{~m} \mathrm{Ma}^{-1}\right)$ and decrease towards the south $\left(74.38 \pm 11.49 \mathrm{~m} \mathrm{Ma}^{-1}\right.$ ) (Mandal et al., 2015).

\section{Geological evolution of major river basins of India}

\section{Antecedent large Himalayan rivers}

The geological evolution of antecedent river basins of the Himalaya is related to the Himalayan mountain building process. The dominant geological divisions within the antecedent rivers are the Tethys Himalaya, the Higher Himalaya and the Lesser Himalaya. The Himalayan mountain building process was initiated with continentcontinent collision between the Indian and Eurasian plates around 55 Ma (Valdiya, 1998; Leech, 2005). The Indus-Tsangpo Suture Zone defines the northern limit of the Tethys Himalaya which marks the origin of large antecedent river systems. The Tethys Himalaya forms the northern most hinterland of these river basins. The Tethys Himalaya is a high elevation (average 5,000 m), low relief region $(\sim 500 \mathrm{~m})$ comprising of nearly non-metamorphosed fossil bearing marine sediments ranging in age from Neoproterozoic ( $\sim 60 \mathrm{Ma})$ to Eocene ( $\sim 65 \mathrm{Ma})$. Towards its south, the Tethys Himalaya is separated from the Higher Himalaya by a low angle normal fault known as the South Tibet Detachment Zone (STDZ). Subsequent compression led to the formation of the high relief topographic ridge called the Higher
Himalayan crystalline complex represented by high-grade metamorphic rocks affected by intense ductile deformation and migmatization of the Proterozoic (2200 - $1800 \mathrm{Ma}$, 500-550 Ma with younger deformation at $\sim 20 \mathrm{Ma}$ ) age with the major rock assemblages namely mica-schists, quartzite, gneisses and migmatites (Yin and Harrison, 2000; Ramakrishnan and Vaidyanadhan, 2008; Valdiya, 2015). Owing to continuous compressive stresses and the subsequent buckling of the crust, the formation of the Main Central Thrust (MCT) resulted to the south of the Higher Himalaya ( 21 $2 \mathrm{Ma})$. The high relief topography subsequently led to the establishment of the major drainage systems, such as Indus, Sutlej, Ganga, Ghaghra, Gandak and Kosi rives. Further, the compression and the topography buildup continued to propagate southwards, which lead to formation of the folded and faulted Lesser Himalayan sequence comprising Paleoproterozoic ( 1800 Ma) to Paleozoic ( $550 \mathrm{Ma})$ sequences of low-grade metamorphic and meta-sedimentary rocks. The Main Boundary Thrust (MBT) which formed in the later stages of the Himalayan orogeny $\sim 10 \mathrm{Ma}$ forms the southern limit of the Lesser Himalaya (Meigs et al., 1995). The Himalayan deformation moved further southward and now the MFT is the neotectonically active thrust of the Himalaya (Valdiya, 2003; Jayangondaperumal et al., 2011; Hirschmiller et al., 2014; Dey et al., 2018). The southward build-up of high relief and high slope topographic ridges promoted generation of several other tributaries which contributed their discharge into the earliest formed drainage systems, thus increasing the erosive capacity of the main channel to maintain its course by dissecting the uplifting Himalayan terrain (Gupta, 1997). Subsequent headward erosion further helped in the expansion of the drainage basin of the antecedent large Himalayan river basins. The height of the Himalayan mountains has also a significant effect on the distribution of glacial cover and on monsoonal climates of Asia that has consequently governed the river hydrology and discharge. Various phases of Indian Summer Monsoon (ISM) strengthening in relation of Himalayan uplift have been suggested by different authors with major peaks at $\sim 10,5$ and 3 Ma (Quade et al., 1989; Zhisheng et al., 2001; Sanyal and Sinha, 2010; Tada et al., 2016).

\section{Himalayan foothills-fed rivers}

The revival of tectonic activity brought about the deformation and folding of the Siwalik sediments towards the end of the Pleistocene $(\sim 1.6 \mathrm{Ma})$ and the formation of the Siwalik Range (Valdiya, 2015). The intensity of deformation was strongest along the MBT, thus bringing the Lesser Himalaya over the Siwalik sequence. These ridges with elevation $\sim 1000-350 \mathrm{~m}$ became the hinterland for younger drainage systems known as the foothills-fed rivers (Sinha and Friend, 1994). Since the Siwalik range comprises sedimentary rocks with much higher erodibility than the Higher and Lesser Himalayan rocks, they have not been able to maintain relief as high as the Higher or Lesser Himalaya. Hence, these rivers have relatively smaller hinterland regions. The Siwalik range is bounded to the south by the Himalayan Frontal fault which is currently an active fault (Peltzer and Saucier, 1996; Valdiya, 2015; Srivastava et al., 2016; Jayangondaperumal et al., 2018). Further, various active thrusts between MBT and MFT resulted in significant topographic variability and dynamic surfaces (Thakur et al., 2014; Dey et al., 2016; Kaushal et al., 2017). Various workers have also highlighted the state of steady state in the Sub Himalayan terrain because of higher uplift rate and high erosion rate from the soft sedimentary rocks (Hurtrez et al., 1999; Barnes et al., 
2011). Hence, the foothills-fed rivers are characterised by higher sediment supply and sediment yield.

\section{North flowing Cratonic rivers}

The high relief regions of the Aravalli mountain range (in the north-west of India) and the Vindhyan (in the south) mountain range formed the headwaters of the cratonic tributaries of the Ganga River basin. The depositional ages of the Vindhyan sediments are between 1,700 Ma and 1,000 Ma (Ray, 2006; Ramakrishnan and Vaidyanadhan, 2008; Chakraborty et al., 2019). The Bundelkhand craton forms the basement and is overlain by the Ganga alluvial sediments. The Himalaya-derived sediments onlapped over the cratonic-derived sediments (Burbank, 1992). Due to continued uplift of the Himalaya and sediment flux, the axial Ganga River shifted southward and so did the cratonic rivers; thereby creating this onlap (Sinha et al., 2009). Currently, the boundary between cratonic and Himalayan sediments lies at the southern margin of the Ganga plains (Sinha et al., 2009).

\section{West flowing Peninsular rivers}

The Son-Narmada fault zone which separates the Vindhyan basin to its north and the Gondwana belt in the south is a deep-seated fault, which extends to the Moho (Rajendran and Rajendran, 1998). Vertical block movements have been reported in both northern and southern regions of the Son-Narmada lineament (West, 1962). The origin of the west flowing Narmada and Tapi rivers is attributed to the tectonic reactivation along the pre-existing Son-Narmada-Tapi fault and the formation of horst and graben structures which are currently occupied by the Narmada and Tapi river basins (Waghmare et al., 2008; Kothyari and Rastogi, 2013). The Son-Narmada and Tapi having an ENE-WSW trend control the course of the main drainage system (Chamyal et al., 2003). The Son-Narmada-Tapi (SONATA) zone extends WNW and is represented by a fault pair, the Narmada rift valley and Satpura horst. The Tapi Fault marks the southern boundary of the Satpura range (Kothyari and Rastogi, 2013). Seismic reflection data for the Son-Narmada lineament reveals that these two west flowing rivers drain through bed rocks, which formed during Precambrian (Kaila, 1986 and Dixit et al., 2010), and witnessed tectonic reactivation in the Late Cretaceous (Kothyari and Rastogi, 2013). Most of the west flowing rivers drain over Deccan basalts, which overlies the granitic gneisses. The Narmada rift is seismically active and has experienced earthquakes of $M>5.5$ and 6.3 in the past 70 years. Seismic reflection and gravity anomaly studies suggest the presence of high density material at a shallow depth below the Narmada Fault, suggesting that the Narmada fault is active with an NE to ENE and NW to EW orientation of the fault plane (a cause for the recent Broach and Jabalpur earthquakes respectively) (Rajendran and Rajendran, 1998; Mandal et al., 2000).

\section{East flowing Peninsular rivers}

The regional topography of the Peninsular region is related to its separation from eastern Gondwanaland and rifting along its western margin, which resulted in an eastward regional tilt to this landmass (Ramakrishnan and Vaidyanadhan, 2008). Among the Peninsular rivers, the Godavari River has been developed over a pre-existing graben whose antiquity goes back to the Mesoproterozoic (Valdiya, 2015). The northern part of the Godavari basin sedimentary successions (deposited over the Precambrian basement rocks) are overlain by the Deccan lava piles (Narula et al., 2000). The Krishna River basin comprises Deccan Traps in the north-western part, crystalline Archean basement rocks in the central part, and Proterozoic sediments of the Cuddapah Group in the east. Most of the headwaters lie along the high relief range of the eastern margin of the Western Ghats and some along the undulating outcrops in the Archean basement. The Cauvery River in the south also largely drains the Precambrian basement rocks comprising relatively higher grade metamorphic rocks such as charnockites, granites and graniticgneisses. Some of the high relief features occur along the mylonite shear zones.

\section{Coastal rivers along the Western Ghat Escarpment (WGE)}

The coastal rivers along the western rift margin of India formed as a result of crustal doming and rifting which preceded the drifting of the Indian subcontinent, resulting in the development of an initial escarpment along the western margin of India (Subrahmanya, 1994, 1998). The formation of the present western Indian margin was affected by the late Cretaceous separation from Madagascar (Gunnell et al., 2003). The continuous stretch of relief created along the escarpment owing to the rifting process created a north-south passive continental margin known as the Western Ghat. The west coast was formed $\sim 65 \mathrm{Ma}$ (Valdiya, 2015). Seismic data recorded along the Konkan deep water basin shows evidence of pre-, syn- and post-rift tectono sedimentary stages of the west coast rifting event (Valdiya, 2015). The entire northern half of the Western Ghat escarpment margin comprises the Deccan Traps (Cretaceous-Palaeocene lava flows), the central part by the Dharwar schist belt and the southern part by Precambrian Charnockites and Granitic-gneisses.

\section{Geomorphic evolution of the major river systems in different geological settings}

Sediment deposition by rivers during the Late Quaternary is preserved in the form of landforms. Geomorphic processes define valley evolution at relatively shorter time scales, which include formation of river terraces, alluvial fans, floodplains and interfluves. Geomorphic processes at such shorter time scales like $10^{3}-10^{5}$ years define the evolution of valley setting. Valley setting further plays an important role in defining modern day river processes (Brierley and Fryirs, 2005). Stratigraphic reconstruction of such sedimentary records have been used to infer geomorphic evolution of the river valleys during the Quaternary time period by analysing variations in river fluxes. However spatial and temporal resolution of such reconstruction depends on the preservation potential of the sedimentary record. The extent of understanding about geomorphic evolution is different for different river basins, which will depend on the geomorphic setting of the river basin. In this context, we summarize the geomorphic evolution of Indian river valleys in different geomorphic setting based on their Quaternary stratigraphic records (Table 2).

\section{Antecedent large Himalayan rivers}

Terrace deposits in the valleys of antecedent rivers provide an insight about their geomorphic evolution in response to climatic and 
Table 2. Geomorphic landforms and evolutionary history of the Indian rivers in response to the Late Quaternary climate change.

\begin{tabular}{|c|c|c|c|c|c|}
\hline MIS & Antecedent river & Foothill rivers & Craton rivers & West flowing & East flowing \\
\hline$\overline{\text { MIS1 }}$ & $\begin{array}{l}\text { Baspa valley: pulse of fluvial } \\
\text { aggradation (9.1-6.5 ka) (Dutta } \\
\text { et al., 2017). } \\
\text { Sutlej valley: Increase in } \\
\text { sediment-transport rates (10-4 } \\
\text { ka) and intensified monsoon } \\
\text { (Bookhagen et al., 2005). } \\
\text { Alaknanda river: Terrace } \\
\text { incision at 11 ka (Ray and } \\
\text { Srivastava, 2010). } \\
\text { Ganga Plains, aggradational } \\
\text { periods (15-12, and 2.5 ka BP) } \\
\text { separated by incision ( 7 ka BP) } \\
\text { (Roy et al., 2012). } \\
\text { Alakananda valley: Aggradation } \\
\text { around } 8 \text { ka (Juyal et a., } 2010 \text { ). } \\
\text { Yamuna valley: Fluvial } \\
\text { aggradation (7-4 ka; } 3-2 \text { ka; } \\
\text { and <2 ka ka BP) separated by } \\
\text { incision between } 11 \text { and } 7 \text { ka, } 4 \\
\text { and } 3 \text { ka and less than } 2 \text { ka } \\
\text { (Dutta et al., 2012). }\end{array}$ & $\begin{array}{l}\text { The fluvial terraces along } \\
\text { the Baghmati, Bakeya, } \\
\text { Narayani, and Ratu rivers } \\
\text { in the Nepal Sub- } \\
\text { Himalaya revealed four } \\
\text { major episodes of strath } \\
\text { terrace formation between } \\
9.2 \text { and } 2.2 \text { cal. kyr BP } \\
\text { (Delcaillau, 1992; Lave } \\
\text { and Avouac, } 2000 \text { and } \\
\text { 2001) }\end{array}$ & $\begin{array}{l}\text { Belan river : fluvial and } \\
\text { eolian sand (14-7 ka BP) } \\
\text { corresponds to a period of } \\
\text { climatic instability (Gibling } \\
\text { et al., 2008). }\end{array}$ & $\begin{array}{l}\text { Narmada: Slack-water deposits } \\
(\sim 5 \mathrm{ka}) \text { in Central Narmada basin } \\
\text { (Kale et al., 1993). } \\
\text { High magnitude floods preserved } \\
\text { as benches of slack-water deposit } \\
\text { (Kale et al., 1994; Ely et al., } \\
\text { 1996). } \\
\text { Geomorphic evolution was } \\
\text { controlled by differential uplift } \\
\text { along the Narmada-Son Fault } \\
\text { (Chamyal et al., 2002) Luni river: } \\
\text { Incision at } ~ 10 \text { and } 3 \text { ka in Luni } \\
\text { river and less active with aeolian } \\
\text { deposition during arid phase } \\
\text { between } 14 \text { and } 11 \text { ka (Jain et al., } \\
\text { 2004) }\end{array}$ & $\begin{array}{l}\text { Cauvery: Incision between } 10 \text { and } 4.5 \\
\text { ka BP (Kale and Rajaguru, 1987). } \\
\text { Paleoflood deposits represent high } \\
\text { discharge at } \sim 8 \mathrm{ka} \text { (Kale et al., 2010). }\end{array}$ \\
\hline \multirow[t]{2}{*}{ MIS2 } & $\begin{array}{l}\text { Baspa valley: rock avalanches } \\
\text { (>23 ka); Lake sedimentation } \\
\text { reduced during cold and arid } \\
(23-18 \mathrm{ka}) \text { and increased during } \\
\text { warm and humid (18-11.5 ka) } \\
\text { (Dutta et al., 2017). }\end{array}$ & & $\begin{array}{l}\text { Son and Belan:Prolonged } \\
\text { aggradation ( } 39 \pm 9 \text { to } 16 \pm 3 \\
\text { ka) with sustained vertical } \\
\text { incision after } 16 \mathrm{ka} \text { (Williams } \\
\text { et al., 2006). }\end{array}$ & $\begin{array}{l}\text { Narmada: Alluvial fan, and debris- } \\
\text { flow deposits during the } \\
\text { Pleistocene (Chamyal et al., } \\
\text { 1997). } \\
\text { Luni: Incision at } 14 \text { ka (Jain et al., } \\
\text { 2004). }\end{array}$ & $\begin{array}{l}\text { Cauvery: Aggradation ( }>30-10 \mathrm{ka} \\
\text { BP) (Kale and Rajaguru, 1987). } \\
\text { Fluvial aggradation ( } 30-40 \mathrm{ka}) \text {, } \\
\text { otherwise it was modest fluvial } \\
\text { erosion during last } \sim 40 \mathrm{ka} \text { (Kale, } \\
\text { 2014) }\end{array}$ \\
\hline & $\begin{array}{l}\text { Sutlej: Increase in sediment } \\
\text { transport rates }(29-24 \mathrm{ka}) \\
\text { (Bookhagen et al., 2005). } \\
\text { Alaknanda river: Aggradation } \\
\text { and landslide generated deposits } \\
\text { (18-11 ka) (Ray and Srivastava, } \\
2010) \text {. } \\
\text { Alakananda valley: valley fill } \\
\text { aggradation } \sim 26 \mathrm{ka}, 18 \text { ka and } \\
15 \text { ka (Juyal et al., 2010). } \\
\text { Yamuna valley: Aggradation } \\
(\sim 15 \text { to } 11 \text { ka BP) followed by } \\
\text { incision at } \sim 11 \text { ka BP (Dutta et } \\
\text { al., 2012). }\end{array}$ & & $\begin{array}{l}\text { Betwa: Thick floodplain } \\
\text { deposition of Unit-4 (Sinha } \\
\text { et al., 2005b). }\end{array}$ & $\begin{array}{l}\text { Mahi and Sabarmati rivers are } \\
\text { characterized by fluvial inactivity } \\
\text { and aeolian deposition (Jain et al., } \\
\text { 2004). }\end{array}$ & \\
\hline MIS3 & $\begin{array}{l}\text { Baspa valley: Alluvial fan } \\
\text { progradation ( 49-45 ka) } \\
\text { (Dutta et al., 2017). } \\
\text { Alaknanda: Aggradation of } \\
\text { channel bars, debris flow ( 49- } \\
25 \mathrm{ka} \text { ) (Ray and Srivastava, } \\
2010 \text { ). Debris flow terraces } \\
\text { developed during MIS } 3 \\
\text { followed by a phase of incision } \\
\text { after } 45 \text { ka (Juyal et al., 2010). } \\
\text { Ganga Plains: aggradational } \\
\text { periods (37, 28 ka BP) separated } \\
\text { by incisional episodes (30, and } \\
\text { 20, ka BP) (Roy et al., 2012). } \\
\text { Yamuna valley: Aggradation } \\
\text { ( 37 to } 24 \text { ka BP) followed by } \\
\text { incision phase at } \sim 24 \text { ka BP } \\
\text { (Dutta et al., 2012). }\end{array}$ & & $\begin{array}{l}\text { Son and Belan: Prolonged } \\
\text { aggradation ( } 39 \pm 9 \text { to } 16 \pm 3 \\
\text { ka) (Williams et al., 2006). } \\
\text { Betwa: gravel bed channels } \\
\text { (Sinha et al., 2005b). }\end{array}$ & $\begin{array}{l}\text { Mahi: Fluvial aggradation ( } 52 \text { to } \\
44 \text { ka and } 30 \text { to } 37 \mathrm{ka} \text { ) and } \\
\text { intermittent pedogenesis between } \\
40 \text { and } 25 \mathrm{ka} \text { (Juyal et al., 2000). } \\
\text { Fluctuations in ISM ( } 37 \mathrm{ka} \text { to } 27 \\
\text { ka) recorded in the alluvial } \\
\text { successions (of the Banas and } \\
\text { Saraswati rivers) in the northern } \\
\text { Gujarat alluvial plain } \\
\text { (Bhattacharya et al., 2017). }\end{array}$ & \\
\hline MIS4 & $\begin{array}{l}\text { Ganga Plains, aggradational } \\
\text { period (74-61 ka BP) (Roy et } \\
\text { al., 2012). }\end{array}$ & & $\begin{array}{l}\text { The Betwa tributary of } \\
\text { Yamuna river in the southern } \\
\text { Ganga plains shows flood- } \\
\text { plain accretion with strong } \\
\text { pedogenic event (Unit-2) } \\
\text { (Sinha et al., 2005b). }\end{array}$ & $\begin{array}{l}\text { Mahi: Gravel bedload stream } \\
\text { deposit (Juyal et al., 2000). }\end{array}$ & \\
\hline MIS5 & & & $\begin{array}{l}\text { Belan: fluvial activity ( } 85 \\
\text { and } 72 \text { ka BP) (Gibling et al., } \\
\text { 2008). Son and Belan: } \\
\text { valley-fill aggradation at } 73 \\
\text { ka (Williams et al, 2006). } \\
\text { Betwa: Four major allostrati- } \\
\text { graphic units starting with } \\
\text { high energy gravel deposi- } \\
\text { tion (Sinha et al., 2005b) }\end{array}$ & $\begin{array}{l}\text { Luni: Gravel bedload aggradation } \\
\text { during MIS5e (Jain et al., 2004). } \\
\text { Mahi: Marine clays ( } 74 \mathrm{ka} \text { ) in } \\
\text { distal reaches (Juyal et al., 2000). } \\
\text { Sabarmati: Mud aggradation (Jain } \\
\text { and Tandon, 2003). } \\
\text { Fluvial aggradation ( } 90 \text { to } 84 \mathrm{ka} \text { ) } \\
\text { during stronger ISM in MIS-5 } \\
\text { (Thokchom et al., 2017) }\end{array}$ & \\
\hline
\end{tabular}


tectonic forcings. Climatic variations at $10^{3}-10^{5}$ years time scale in the Himalayan regions played an important role in valley evolution process. Further, spatial climatic variability and glacial cover in different litho-tectonic zones added more variability in valley evolution process.

River valleys in the antecedent Ganga River basin are characterised by various episodes of sediment filling and evacuation at millennial time scale, which resulted in different sets of river terraces in response to climate change events in last 50 ka time period (Ray and Srivastava, 2010; Juyal et al., 2010; Dutta et al., 2012). The terrace formation processes define shape of fluvial valleys in different litho-tectonic terrains of the Himalaya. Devarani and Singh (2014) further highlighted the local control on geomorphic development of river valley. These studies also highlighted absence or little role of tectonics on the geomorphic evolution of fluvial valleys in the tectonically active Himalayan region.

In the neighbouring Sutlej River basin, sediment supply from the northern arid part of the river basin, which lies in the Tethys Himalaya played an important role on valley processes. Monsoon intensification phases during the late Pleistocene (29-24 ka) and Holocene (10-4 ka) leads to a five-fold increase in sediment-transport rates compared to the present-day sediment-flux measured in the Sutlej valley (Bookhagen et al., 2005). It was inferred to be due to deep penetration of the monsoon into the high arid parts of the northwest Himalaya resulting in increased mass wasting (Bookhagen et al., 2005). Thus, the erosion of these internal and high-elevation regions provided the voluminous valley fills in the low-gradient regions during increased precipitation whereas weak and dry ISM intervals led to a decrease in the sediment to water ratio, allowing fluvial incision and terrace formation in the northwest Himalaya (Bookhagen et al., 2006). The aggradation processes in the Baspa valley, on the eastern side of Sutlej valley in the Higher Himalaya, shows aggradation in response to glacial retreat and readjustment of glaciogenic sediment or fluvial sediments from paleolake breaches (Dutta et al., 2017). Hence, climate is the dominant control on geomorphic evolution of river valleys, which was manifested through fluvial and glacial processes.

However, nature of external control was different in neotectonically active Sub-Himalayan area. The river valleys of Narayani, Sapt Kosi, the Kali Gandaki, the Marsyandi, Buri Gandaki, Trisuli, Sun Kosi and Arun in the Nepal Himalaya were strongly governed by tectonics and are actively incising in the Sub-Himalaya to compensate for active thrusting and folding across the MFT(Lave and Avouac, 2001).

Initial chronological data of geomorphic surfaces in the Ganga Plain show evidence of different phases of aggradation and degradation, although these were not synchronous with aggradation and degradation in the hinterland Himalayan area (Srivastava et al., 2003). Valley evolution in the Ganga Plains are governed by different set of external controls (Tandon et al., 2006). The valley formation and channel incision near the Himalayan front was governed by tectonic and climatic variability, whereas climate was the major controlling factor in defining valley formation in the craton margin area (Tandon et al., 2006). The eastern Ganga plains is characterized by minimal incision of the modern megafans and interfan rivers in response to high sediment supply, low stream power and high subsidence (Jain and Sinha, 2003a; Sinha et al., 2005a; Tandon et al., 2006; Dingle et al., 2016). The role of climate in valley morphology was also highlighted by Roy et al. (2012) through stratigraphic analysis in the middle Ganga Plains. Five aggradational periods (74-61, 37,
$28,15-12$, and $2.5 \mathrm{ka} \mathrm{BP}$ ) in the area correspond to times of declining monsoonal strength separated by incisional episodes (30, 20, $7 \mathrm{ka}$ BP) that correspond broadly with periods of monsoonal intensification (Roy et al., 2012).

Multiple controls at different (regional and local) scales and nonsynchronous aggradation or degradation events highlights disconnectivity in the geomorphic processes in a river basin. These data have also highlighted that upstream control on aggradationdegradation processes at downstream reaches is not uniform and it may be limited within a given time frame.

\section{Himalayan foothill-fed rivers}

Geomorphic evolution of river valleys in the Sub-Himalaya is strongly governed by active tectonics (Delcaillau, 1992; Lavé and Avouac, 2000, 2001). Fluvial terraces along the Baghmati, Bakeya, Narayani, and Ratu rivers in the Nepal Sub-Himalaya revealed four major episodes of strath terrace formation between 9.2 and 2.2 cal. kyr BP in response to active tectonics (Delcaillau, 1992; Lavé and Avouac, 2000, 2001). Further, geomorphic response to tectonic forcing was spatially variable which was the reflection of variability in uplift rate along active faults between MFT and HFT. Further downstream, valley evolution in the fan setting is governed by climate change events (Singh et al., 2001). Multiple phases of sediment filling and evacuation occurred in the Dehradun valley in last 50 ka period, which were mostly in response to climate change events.

The smaller rivers in the Western Ganga Plains were incised around $10 \mathrm{ka}$ in response to monsoon intensification, whereas rivers in the Eastern Ganga Plains aggraded (Pratt et al., 2002; Dutta et al., 2012; Jain et al., 2012). The average sedimentation rate in the Eastern Ganga plains is $0.7-1.5 \mathrm{~mm} / \mathrm{yr}$ (Sinha et al., 1996), which is much higher in comparison to the western Ganga plains (0.2-0.3 mm/yr) (Chandra, 1993; Joshi and Bhartiya, 1991; Rajagopalan, 1992). However, in the present day scenario, a comparison of degradation rates (based on rating curves of direct storm run-off) of small rivers show higher values $(1.0 \mathrm{~mm} / \mathrm{yr})$ for the Rapti river in the western Ganga plains compared to the value of $0.6 \mathrm{~mm} / \mathrm{yr}$ for the Baghmati river in the eastern Ganga plains (Andermann et al., 2012).

\section{North flowing Cratonic rivers}

Cratonic rivers have deeply incised channels, mostly associated with wide belts of Badlands and found to be sensitive to climate change events at millennial time scale. The Son and Betwa river valleys are characterised by multiple phases of aggradation-degradation in response to climate events in last $73 \mathrm{ka}$ (Williams et al., 2006; Gibling et al., 2008). The stratigraphic section at Kotra on the Betwa River, a tributary of the Yamuna river, also shows five discontinuities that bound four alternating high and low energy fluvial deposits at different times (Sinha et al., 2005b).

\section{West flowing Peninsular rivers}

Tectonically controlled Narmada and Tapi river valleys evolved through high magnitude flood events. The incised bedrock channel of the Narmada River along the Son-Narmada Fault zone provides space for preservation of slack-water deposits in tributary channels, which are good archives of paleofloods. Several slackwater deposits ( 3 to $10 \mathrm{~m}$ thick) are present at the mouths of tributaries of the Narmada 
and Tapi rivers (Kale et al., 1993, 1994; Ely et al, 1996). High magnitude floods in the Narmada and Tapi rivers coincide with midto late Holocene rise in monsoon precipitation (Kale et al., 1993, 1994). Further, the magnitude and frequency of severe floods in the Narmada River increased in recent years (1951-1991) in comparison to $\sim 1,700$ yr paleoflood records (Ely et al., 1996). Clustering of major flood events during the early Holocene humid phase in the Narmada and Tapi basins suggest an intimate link between magnitude and frequency of floods and long term fluctuations in monsoon rainfall (Mishra and Rajaguru, 1993; Kale et al. 1994, 2003).

The lower Narmada valley evolved through geomorphic processes, which were also governed by neotectonic forcing and pre-existing lineaments (Chamyal et al., 1997; 2002). The geomorphic evolution of other west flowing rivers, Mahi and Sabarmati, occurred mainly during the Late Quaternary in response to climate change (aggradation during sea-level rise) and a change to drier conditions during the Holocene resulted in aeolian sand deposition.

A stratigraphic section along the Mahi River provides a geomorphic history of $\sim 74 \mathrm{ka} \mathrm{BP}$. the lower most unit of which is marine clay (Juyal et al., 2000). It is coeval with the phase of mud aggradation in the inland reaches of the Sabarmati river (Jain and Tandon, 2003). The Mahi River valley witnessed major aggradation events governed by different river forms ranging from a gravel bedload braided river system to mixed load meandering rivers in last $\sim 50 \mathrm{ka}$ (Juyal et al., 2000). The overbank deposit of the meandering rivers was also characterised by intermittent pedogenesis with extensive red horizons in the Mahi River and in the Sabarmati River valley at different time periods (Tandon et al., 1997; Juyal et al., 2000; Jain and Tandon, 2003). The meandering river deposits were followed by fluvial inactivity and aeolian deposits, however, meandering streams were re-established during the 14-11 ka period followed by river incision during the early Holocene, perhaps in response to climatic amelioration and reduced sediment availability (Jain et al., 2004).

\section{East flowing Peninsular rivers}

The Godavari, Bhima and Krishna rivers originate in the elevated high rainfall zone of the Western Ghats and flow eastward through the area covered by Deccan Trap basalt of Cretaceous - Eocene age where there is an uneven distribution of rainfall with two-third of the drainage area in the rain shadow zone of the Western Ghats. Stratigraphic sections along the late Quaternary floodplain deposits include sandy-pebbly-cobbly gravels overlain by non-calcareous dark brown sandy-silts, with gravelly lenses (Kale and Rajaguru, 1987). These processes coincide with regional climatic changes of the late Quaternary as well as the sea level changes along the west coast of India. The major aggradation (>30-10 ka BP) coincided with the weakening of the south-west monsoon, including that during the LGM, and deposition of fine sediments between 17 and $10 \mathrm{ka} \mathrm{BP}$. Incision took place between 10 and $4.5 \mathrm{ka}$ BP during the early Holocene because of increased runoff; similarly, increased continentality and aridity during low sea-level and sea recession by $>200 \mathrm{~km}$ led to fluvial aggradation in contrast to incision during the high sea-level (Kale and Rajaguru, 1987).

The midstream part of the Cauvery canyon was tectonically rejuvenated during the time when the monsoon system was established over the Indian region about 8-10 Ma ago (Kale et al, 2014). Further, the fluvial aggradation phase in the Cauvery basin dates back to $30-$ $40 \mathrm{ka}$ BP and low sediment load in the modern channel together suggests modest fluvial erosion during the last $~ 40$ ka (Kale et al., 2014). This period was also characterised by short-term, high discharge events by flash floods, as manifested in paleoflood deposits in the upper Cauvery catchment (Kale et al., 2010). These flood events occurred in response to increased monsoon variability in the middle Holocene ( 8 ka) (Kale et al., 2010). This suggests that sediment production in peninsular rivers occurs in tectonically produced old topography and is transported intermittently during climatically controlled high discharge events.

\section{Discussion}

Role of basin evolution on modern day river systems inherent controls of a river basin, namely geology and climate, strongly define the modern day river behaviour (process) and appearance (morphology). The presence of 'landscape memory'(sensuo Brierley, 2010) suggests a need for a holistic approach to river studies by incorporating river evolution and the role of inherent basin characteristics. Some recent approaches to geomorphic classification of river systems also includes landscape characteristics and trajectories of geomorphic systems as an important parameter (Rosgen, 1994; Montgomery and Buffington, 1998; Brierley and Fryirs, 2005; Sinha et al, 2017); this helps to understand the future of a river system in response to external forcing/disturbance.

Geological evolution of a basin area at million year time scale governs the origin of river and landscape characteristics, whereas landscape dynamics in response to external forcings (tectonics, climate or sea level) are represented by geomorphic processes at millennial time scales. These geological and geomorphic processes in different river basins provide an opportunity to analyse the role of 'landscape memory'in geomorphic evolution in modern-day rivers.

The geological characteristics of the Indian sub-continent presents significant diversity. The tectonically active landscape of the Himalaya is characterised by high relief and steep slopes, which causes high sediment supply and discharge. The Higher Himalaya is the main source of sediments (Wasson, 2003; Lavé and Avouac, 2001; Singh, et al., 2008). Steep slopes of the river long profiles in the Higher Himalaya which are maintained owing to the higher rock resistance cause higher stream power along its channels (Sonam and Jain, 2018). Intense orographic precipitation due to high relief of the Higher Himalaya and glacial-melt runoff from glaciated area provides more discharge to further support higher stream power values along the steep slopes. The antecedent Himalayan rivers are characterised by large basin area, high sediment supply, higher discharge and incised valleys in response to uplifting terrains. These mountain-fed rivers (Sinha and Friend, 1994) are characterised by distinct geomorphic characteristics (braided channel pattern) and processes (very high rate of sediment transportation) in comparison to other rivers. However, a significant geomorphic diversity in these rivers in different parts of the Himalayas has been documented. The rivers which originate from the steeper parts of the eastern Himalaya have the highest stream power values (with maximum values $\sim 10^{6} \mathrm{~W} / \mathrm{m}$ ) and hence transport much higher amounts of sediment (Sonam and Jain, 2018). Higher stream power values along river long profiles of the Nepal Himalaya also explain high erosion rates and high sediment supply in the eastern Himalayan tributaries of the Ganga River (Jain and Sinha, 2003a; Sinha et al., 2005a; Sonam and Jain, 2018). High sediment supply also causes extensive deposition in the downstream regions. It makes the channels shallower, which further causes frequent flooding and 
migration of channels (Gole and Chitale, 1966; Wells and Dorr, 1987; Mohindra et al., 1992; Sinha and Jain, 1998; Jain and Sinha, 2003b, 2004).

Foothill-fed river systems are also characterised by high sediment load. Highly erodible and rapidly uplifting sedimentary rocks in the Himalaya provide substantial sediment loads (Tripathi et al., 2004; Jain et al., 2008). Erosion rates in the Siwalik terrain are the highest in the Himalaya (Lupker et al., 2012; Olen et al., 2016). Therefore, these rivers are also known for very high sediment yields (Sinha and Friend, 1994). High sediment yield in these river systems is responsible for extensive channel sedimentation in downstream alluvial reaches, frequent flooding and braided or anabranching channel patterns (Jain and Sinha, 2003b, 2003c, 2004). Further, similar to the antecedent rivers, morphology and processes are different from west to east (Jain and Sinha, 2003a; Sinha et al., 2005a). This variation is because of high uplift rates ( $15 \mathrm{~mm} / \mathrm{a})$ along the MFT in the Nepal Himalaya compared to western Himalayas $(6.9 \mathrm{~mm} / \mathrm{a})$ (Peltzer and Saucier, 1996; Wesnouskyet al., 1999; Lave and Avouac, 2000; Thakur et al., 2014; Dey et al., 2019) and higher rainfall in the eastern hinterland and Ganga plains in comparison to the western hinterland and Ganga plains (Sinha et al., 2005a).

The west flowing Narmada and Tapi rivers have a linear course as their channels are developed in a rift and graben setting. Most of the basin area is characterised by basaltic rocks, which are highly susceptible to weathering. These rivers have some of the highest sediment concentration values among all cratonic rivers owing to the dominance of the basaltic rocks (Sonam and Jain, 2017). Further, the Narmada and Tapi rivers have typical box-shaped channel cross sections which implies rapid increase in specific stream power conditions in the river channel during high discharge conditions in the monsoon season (Kale and Hire, 2004; Kale, 2007). Flood power analysis also suggests that modern day channel morphology of the bedrock as well as alluvial channel reaches of the Tapi River are maintained by large-magnitude floods (Kale and Hire, 2004). Specific stream power values during the highest flood events in these west flowing rivers were estimated in the range of $290-325 \mathrm{~W} / \mathrm{m}^{2}$ which is significantly higher than the threshold required to transport boulder material (Kale, 2007). Incised valleys also provide good accommodation space for slack water deposits, which provides excellent archives for paleoflood data and flow response to climate change (Ely et al., 1996; Kale et al., 2003; Sridhar, 2007).

The cratons of the Indian Peninsula India have low relief, and a regional eastward tilted landmass consisting of high-grade metamorphic and meta-sedimentary rocks resulting in large river basins on gently sloping surfaces. The long profile of the river systems in this terrain is also governed by long term tectonic evolution of the area (Richards et al., 2016). The low relief terrain and highly resistant metamorphic rocks are also responsible for lesser sediment supply (Sonam and Jain, 2017). Therefore, the east flowing rivers, namely Krishna, Godavari and Cauvery, are supply-limited, which is evident from their dominantly bedrock channels with insignificant sediment deposits. Further, these rivers are moderately incised with wider channels in comparison to the west flowing channels owing to low erosion rates. Wider channels further reduce effectiveness of stream power by lowering specific stream power values, which leads to deposition at downstream reaches (Sonam and Jain, 2017). The downstream parts of the rivers are alluvial owing to the large channel cross-section width and low slope.

The coastal rivers along the Western Ghats have different hydro- geomorphic attributes because of topographic characteristics of the Western Ghat escarpment (WGE). The WGE has relatively higher relief, which is responsible for focussed precipitation on the escarpment due to an orographic effect. High intensity rainfall over the escarpment leads to high runoff and intense erosion. This leads to escarpment retreat due to fluvial erosion (Kale and Subbarao, 2004). The landward retreat of the escarpment created space for small basins of coastal rivers. These coastal rivers of the WGE are characterised by longitudinal basin shape, steep slope and high discharge (Guha and Jain, 2017). Further, hydro-geomorphic characteristics of the modern rivers in the WGE are variable and strongly governed by lithology and topography. Basalt is highly susceptible to weathering in comparison to other Precambrian rocks of the southern WGE (Gurumurthy et al., 2012). Therefore, the rivers in the northern part of the WGE draining the basaltic terrain are characterised by high sediment load in comparison to rivers in the southern WGE (Guha and Jain, 2020). The rocks in the southern WGE are generally less susceptible to weathering, which further governs the relief variation. The relief of the southern part of the WGE is higher than its northern counterpart. Higher strength of Precambrian rocks in the south gives rise to high relief and steepness which is also evident from river profiles (Guha and Jain, 2017). Mandal et al. (2015) further highlighted a major role for topography in the bedrock erosion process on the basis of ${ }^{10} \mathrm{Be}$ cosmonuclide derived erosion rate in the central WGE.

\section{Conclusions}

River systems in India in different landscape settings are characterised by different evolutionary pathways, which in turn have governed their modern day hydro-geomorphic characteristics. A review of geological and geomorphic processes at different time scales highlights a strong role of inheritance and 'landscape memory' in river behaviour and appearance. The main conclusions are as follows

1. The river systems in India have been classified into six major classes on the basis of their geological evolution, climatic and sediment transport characteristics. This first order classification of river systems in diverse tectono-climatic settings provides a basic template to understand the evolution of river systems of the sub-continent and its implications on the modern day river behaviour and processes.

2. Tectonics is a major control on channel morphology. Tectonics, in combination with lithology, governs the topography (relief and steepness), which further influences climatic variability. These inherent parameters define the geomorphic state of a river system. Topography and climate variability directly affects river systems by controlling stream power and sediment supply.

3. In the absence of tectonics, lithological and topographic variability plays an important role in defining geomorphic characteristics of river systems by controlling the catchment erosion rate, sediment supply and channel shape. East flowing peninsular rivers and coastal rivers along the Western Ghats fall in this category.

4. River response to external forcing over geological time scales defines its present day morphology. Deeply incised valleys for most of the river systems were formed during the last monsoon intensification around $10 \mathrm{ka}$, especially for the Himalayan and west flowing rivers. The deeper valleys are 
responsible for concentration of flood power, which further enhances rates of bed level erosion. The valley shape governs modern day river processes, through utilisation of available stream power.

5. Rivers are not isolated linear bodies but are a part of the overall landscape (also called Riverscape), which defines their hydrogeomorphic characteristics. The role of 'landscape memory' in river systems is therefore significant to achieve holistic understanding of a river system.

\section{Acknowledgements}

This paper was finalised while one of the authors (RS) was supported by COFUND fellowship at Durham University, UK. Sonam was supported by $\mathrm{PhD}$ fellowship provided by CSIR-UGC, India (Fellowship No. 061320507-23/06/2013(i)EU-V).

\section{References}

Andermann, C., Crave, A., Gloaguen, R., Davy, P., Bonnet, S. (2012). Connecting source and transport: Suspended sediments in the Nepal Himalayas: Earth and Planetary Science Letters, 351-352, 158-170.

Babu, H. R., Lakshmi, M. P. (2005). Aeromagnetic image of a part of peninsular India and its relation to geology and structure. Exploration Geophysics, 36(2), 250-258.

Barnes, J. B., Densmore, A. L., Mukul, M., Sinha, R., Jain, V. and Tandon, S. K. (2011) Interplay between faulting and base level in the development of Himalayan frontal fold topography. J. Geophys. Res., 116, F03012, doi:10.1029/2010JF001841.

Bawa, N., Jain, V., Shekhar, S., Kumar, N., Jyani, V. (2014) Controls on Morphological Variability and Role of Stream Power Distribution, Yamuna River, western India. Geomorphology, 227, 60-72. doi: 10.1016/j.geomorph.2014.05.016.

Bhattacharya, F., Shukla, A. D., Patel, R. C., Rastogi, B. K., Juyal, N. (2017). Sedimentology, geochemistry and OSL dating of the alluvial succession in the northern Gujarat alluvial plain (western India) - A record to evaluate the sensitivity of a semiarid fluvial system to the climatic and tectonic forcing since the late Marine Isotopic Stage 3. Geomorphology, 297, 1-19.

Bishop, P. (2007). Long-term landscape evolution: linking tectonics and surface processes. Earth Surf. Process. Landf., 32, 329-365.

Bookhagen, B., Thiede, R.C., Strecker, M.R. (2005). Late Quaternary intensified monsoon phases control landscape evolution in the northwest Himalaya. Geology, 33, 149-152.

Bookhagen, B., Fleitmann, D., Nishiizumi, K., Strecker, M.R., Thiede, R.C. (2006). Holocene monsoonal dynamics and fluvial terrace formation in the northwest Himalaya, India. Geology, 34, 601604.

Brierley, G.J. (2010). Landscape memory: the imprint of the past on contemporary landscape forms and processes. Area, 42, 76-85.

Brierley, G.J., Fryirs, K.A. (2005). Geomorphology and River Management: Applications of the River Styles Framework. Blackwell Publishing, Oxford, UK, p. 398.

Burbank, D. W. (1992). Causes of recent Himalayan uplift deduced from deposited patterns in the Ganges basin. Nature, 357(6380), 680.

Chamyal, L.S., Khadkikar, A.S., Malik, J.N., Maurya, D.M. (1997). Sedimentology of the Narmada Alluvial Fan, Western India. Sed. Geol., 107, 263-279.

Chamyal, L.S., Maurya, D.M., Bhandari, S., Raj, R. (2002). Late Quaternary geomorphic evolution of the Lower Narmada Valley,
Western India: implications for neotectonic activity along the Narmada-Son Fault. Geomorphology, 46 (3-4), 177-202.

Chamyal, L. S., Maurya, D. M., Raj, R. (2003). Fluvial systems of the drylands of western India: a synthesis of Late Quaternary environmental and tectonic changes. Quaternary International, 104(1), 69-86.

Chandra, S. (1993). Fluvial landforms and sediments in the northcentral Gangetic Plain, India. PhD (unpublished) thesis, University of Cambridge, Cambridge, UK.

Chakraborty, P.P., Tandon, S. K., Roy, S. B., Saha, S., Paul, P. P. (2019) Proterozoic sedimentary basins of India. In: Gupta, N. and Tandon, S.K., (eds) Geodynamics of the Indian Plate Evolutionary Perspectives, Springer (In Press)

Delcaillau, B. (1992). PhD Thesis, Les Siwaliks de 1'Himalaya du Nepal Oriental, Fonctionnemenett Evolution, CNRS, Paris, pp 205.

Devrani, R., and Singh, V. (2014). Evolution of valley-fill terraces in the Alaknanda Valley, NWHimalaya: Its implication on river response studies. Geomorphology, 227, 112-122.

Dey, S., Thiede, R. C., Schildgen, T. F., Wittmann, H., Scherler, D., Bookhagen, B., Strecker, M.R. (2016). Holocene internal shortening within the northwest Sub-Himalaya: out-of-sequence faulting of the Jwalamukhi Thrust, India. Tectonics. 35, 26772697.

Dey, S., Kaushal, R.K., Sonam, Jain, V. (2018) Spatiotemporal Variability of Neotectonic Activity Along the Southern Himalayan Front: A Geomorphic Perspective. Journal of Geodynamics. (doi.org/10.1016/j.jog.2018.09.003).

Dingle, E. H., Sinclair, H. D., Attal, M., Milodowski, D. T., Singh, V. (2016). Subsidence control on river morphology and grain size in the Ganga Plain. American Journal of Science, 316(8), 778812.

Dixit, M. M., Tewari, H. C., Rao, C. V. (2010). Two-dimensional velocity model of the crust beneath the South Cambay Basin, India from refraction and wide-angle reflection data. Geophysical Journal International, 181(2), 635-652.

Dutta, S., Suresh, N. Kumar, R. (2012). Climatically controlled Late Quaternary terrace staircase development in the fold-and-thrust belt of the Sub Himalaya. Palaeogeography, Palaeoclimatology, Palaeoecology, 356, 16-26.

Dutta, S. Mujtaba, S. A. I., Saini, H. S., Chunchekar, R., Kumar, P. (2017). Geomorphic evolution of glacier-fed Baspa Valley, NW Himalaya: record of Late Quaternary climate change, monsoon dynamics and glacial fluctuations. In: Pant N.C., Ravindra R., Srivastava, D., Thompson, L.G., (eds) The Himalayan cryosphere: past and present, Special Publications, 462. Geological Society, London.

Ely L. L., Enzel, Y., Baker, V. R., Kale, V.S., Mishra, S. (1996). Changes in the magnitude and frequency of late Holocene monsoon floods on the Narmada River, central India. Geological Society of America Bulletin, 108, 1134-1148.

Gibling, M. R., Tandon, S. K., Sinha, R. Jain, M. (2005). Discontinuity-bounded alluvial sequences of the southern Gangetic Plains, India: aggradation and degradation in response to monsoonal strength. Journal of Sedimentary Research, 75(3), 369-385.

Gibling, M.R., Sinha, R., Roy, N.G., Tandon, S.K., Jain, M. (2008). Quaternary fluvial and eolian deposits on the Belan River, India: paleoclimatic setting of Paleolithic to Neolithic archeological sites over the past 85,000 years. Quaternary Science Reviews, 27, 392411.

Gole C.V., Chitale S.V. (1966). Inland delta building activity of Kosi river. Journal of the Hydraulics Division, Proceedings of the American Society of Civil Engineers 92 (HY2), 111-126. 
Gopal, B. (2016).Unique geological and geomorphic features of River Ken with a bedrock channel. Current science, 111(12), 1914-1916.

Guha, S., Jain, V. (2020). Role of inherent geological and climatic characteristics on landscape variability in the tectonically passive Western Ghat, India. Geomorphology, 350, 106840.

Gunnell, Y., Gallagher, K., Carter, A., Widdowson, M., Hurford, A. J. (2003). Denudation history of the continental margin of western peninsular India since the early Mesozoic-reconciling apatite fission-track data with geomorphology. Earth and Planetary Science Letters, 215(1-2), 187-201.

Gupta, A. (1988). Large floods as geomorphic events in the humid tropics, In: V. R. Baker, R. C. Kochel, and P. C. Patton (eds), Flood Geomorphology, Wiley, New York, pp. 151-177.

Gupta, S. (1997). Himalayan drainage patterns and the origin of fluvial megafans in the Ganges foreland basin. Geology, 25(1), 11-14.

Gurumurthy, G.P., Balakrishna, K., Riotte, J., Braun, J.-J., Audry, S., Shankar, H.U., Manjunatha, B.R. (2012). Controls on intense silicate weathering in a tropical river, southwestern India. Chemical Geology, 300, 61-69.

Hirschmiller, J., Grujic, D., Bookhagen, B., Coutand, I., Huyghe, P., Mugnier, J.L., Ojha, T., 2014. What controls the growth of the Himalayan foreland fold-and-thrust belt? Geology 42, 247-250. doi: $10.1130 / \mathrm{g} 35057.1$

Hurtrez, J. E., Lucazeau, F., Lave, J. and Avouac, J. P. (1999) Investigation of the relationships between basin morphology, tectonic uplift, and denudation from the study of an active fold belt in the Siwalik Hills, central Nepal. J. Geophys. Res., 104, 12779-12796.

Jain, M., Tandon, S. K. (2003). Fluvial response to Late Quaternary climate changes, western India. Quaternary Science Reviews Fluvial response to rapid environmental change, 22 (20), 2223 2235.

Jain, M., Tandon, S. K., Bhatt, S. C. (2004). Late Quaternary stratigraphic development in the lower Luni, Mahi and Sabarmati river basins, western India. Proc. Indian Acad. Sci. (Earth Planet. Sci.), 113, (3), 453-471.

Jain, S. K., Agarwal, P. K., Singh, V. P. (2007). Hydrology and water resources of India (Vol. 57). Springer Science and Business Media.

Jain, V., Sinha, R. (2003a). River systems in the Gangetic plains and their comparison with the Siwaliks: A review. Current Science, 84(8), 1025-1033.

Jain, V., Sinha, R. (2003b). Geomorphological manifestation of the flood hazard. Geocarto International, 18 (4), 51-60.

Jain, V., Sinha, R. (2003c). Hyperavulsive-anabranching Baghmati river system, north Bihar plains, eastern India. Zeitschrift fur Geomorphologie, 47(1), 101-116.

Jain, V., Sinha, R. (2004). Fluvial dynamics of an anabranching river system in Himalayan foreland basin, north Bihar Plains, India. Geomorphology, 60 (1-2), 147-170.

Jain, V., Sinha, R. (2005). Response of active tectonics on the alluvial Baghmati River, Himalayan foreland basin, eastern India. Geomorphology, 70, 339-356.

Jain, V., Wasson, R. J., Singhvi, A., McCulloch, M., Sinha, R. (2008). Source area contribution and temporal variation in sediment supply: role of inherent geological and topographic controls. Mountain Building and Climate-tectonic Interaction, Abstract Volume, Wadia Institute of Himalayan Geology, Dehradun.

Jain, V., Tandon, S. K., Sinha, R. (2012). Application of modern geomorphic concepts for understanding the spatio-temporal complexity of the large Ganga river dispersal system. Current Science, 1300-1319.

Jayangondaperumal, R., Wesnousky, S.G., Choudhuri, B.K. (2011). Near-surface expression of early to late Holocene displacement along the northeastern Himalayan frontal thrust at Marbang Korong Creek, Arunachal Pradesh, India. Bulletin of the Seismological Society of America 101(6), 3060-3064.

Jayangondaperumal, R., Thakur, V.C., Joevivek, V., Rao, P.S., Gupta, A.K. (2018). Active Tectonics of Kumaun and Garhwal Himalaya. Berlin (in press): Springer, Singapore. doi: https://doi.org/ 10.1007/978-981-10-8243-6

Joshi, D.D., Bhartiya S.P., (1991). Geomorphic history and lithostatigraphy of a part of eastern Gangetic Plain, Uttar Pradesh. Geological Society of India 37, 569- 576.

Juyal, N., Raj, R., Maurya, D.M., Chamyal, L.S., Singhvi, A.K., (2000). Chronology of Late Pleistocene environmental changes in the lower Mahi basin, western India. Journal of Quaternary Science 15, 501-508.

Juyal, N., Sundriyal, Y.P., Rana, N., Chaudhary, S., Singhvi, A.K., (2010). Late Quaternary fluvial aggradations and incision in the monsoon-dominated Alaknanda Valley, Central Himalaya, Uttrakhand, India. J. Quat. Sci. 25, 1293-1304.

Kaila, K. L. (1986). Tectonic Framework of Narmada Son Lineament-A Continental Rift System in Central India from Deep Seismic Soundings. Reflection Seismology: A global perspective, 13, 133-150.

Kale, V. S. (1998). Monsoon floods in India: A hydro-geomorphic perspective, In: V. S. Kale (ed), Flood Studies in India, Geological Society of India, Bangalore, India, Memoir, Vol. 41, pp. 229256.

Kale, V. S. (2007). Geomorphic effectiveness of extraordinary floods on three large rivers of the Indian Peninsula. Geomorphology, 85(3-4), 306-316.

Kale, V. S. (Ed.). (2014). Landscapes and Landforms of India. World Geomorphological Landscapes. Springer, Dordrecht.

Kale, V. S., Hire, P.S. (2004). Effectiveness of monsoon floods on the Tapi River, India: role of channel geometry and hydrologic regime. Geomorphology, 57, 275-291.

Kale, V.S., Rajaguru, S.N., (1987). Late Quaternary alluvial history of the northwestern Deccan upland region. Nature, 325, 612614.

Kale, V.S., Subbarao, K. V. (2004). Some observations on the recession of the Western Ghat escarpment in the Deccan Trap region, India: based on geomorphological evidence. Transactions Japanese Geomorphological Union, 25 (3). 231-245. ISSN 03891755.

Kale, V. S., Mishra, S., Baker, V. R., Rajaguru, S. N., Enzel, Y., Ely, L. L. (1993). Prehistoric flood deposits on the Choral River, Central Narmada Basin, India. Current Science, 65, 877 - 878.

Kale, V.S., Ely, L.L., Enzel, Y., Baker, V.R. (1994). Geomorphic and hydrologic aspects of monsoon floods on the Narmada and Tapi Rivers in central India. Geomorphology, 10, 157-168.

Kale V. S., Mishra, S., Baker, V.R. (2003). Sedimentary records of palaeofloods in the bedrock gorges of the Tapi and Narmada Rivers, central India. Current Science, 84: 1072-1079.

Kale, V. S., Achyuthan, H., Jaiswal, M., Sengupta, S. (2010). Palaeoflood records from upper Kaveri River, southern India: evidence for discrete floods during Holocene. Geochronometria, 37(1), 49-55.

Kale, V. S., Sengupta, S., Achyuthan, H., Jaiswal, M. K. (2014). Tectonic controls upon Kaveri River drainage, cratonic Peninsular India: Inferences from longitudinal profiles, morphotectonic indices, hanging valleys and fluvial records. Geomorphology, 227, 153-165.

Kaushal, R., Singh, V., Mukul, M., Jain, V. (2017). Identification of deformation variability and active structure using geomorphic markers in Nahan Salient, NW Himalaya, India. Quaternary International, 462, 194-210. DOI: 10.1016/j.quaint.2017.08.015. 
Kothyari, G. C., Rastogi, B. K. (2013). Tectonic control on drainage network evolution in the Upper Narmada Valley: implication to neotectonics. Geography Journal, 2013.

Lavé, J., Avouac, J.P. (2000). Active folding of fluvial terraces across the Siwaliks Hills (Himalayas of central Nepal). J. Geophys. Res., 105, 5735-5770.

Lavé, J., Avouac, J.P. (2001). Fluvial incision and tectonic uplift across the Himalayas of central Nepal. J. Geophys. Res., Solid Earth, 106 (B11), 26561-26591.

Leech, M.L., Singh, S., Jain, A.K., Klemperer, S.L., Manickavasagam, R.M. (2005) The onset of India-Asia continental collision: Early, steep subduction required by the timing of UHP metamorphism in the western Himalaya. Earth and Planetary Science Letters, 234, 83-97.

Lupker, M., Blard, P. H., Lave, J., France-Lanord, C., Leanni, L., Puchol, N., Bourlès, D. (2012). 10Be-derived Himalayan denudation rates and sediment budgets in the Ganga basin. Earth and Planetary Science Letters, 333, 146-156.

Meigs, A. J., Burbank, D. W., Beck, R. A. (1995). Middle-late Miocene (> $10 \mathrm{Ma}$ ) formation of the Main Boundary thrust in the western Himalaya. Geology, 23(5), 423-426.

Mishra, S., Rajaguru, S.N., (1993). Quaternary deposits at Bedaghat, near Jabalpur, Madhya Pradesh. Man and Environment 18, $7-$ 12.

Mohindra R., Parkash B., Prasad J. (1992). Historical geomorphology and pedology of the Gandak megafan, Middle Gangetic Plains, India. Earth Surface Processes and Landforms, 17, 643-662.

Mandal, P., Rastogi, B.K., Gupta, H.K. (2000). Recent Indian earthquakes. Current Science-Bangalore, 79(9), 1334-1346.

Mandal, S.K., Lupker, M., Burg, J.-P., Valla, P.G., Haghipour, N., Christl, M. (2015). Spatial variability of 10 Be-derived erosion rates across the southern Peninsular Indian escarpment: a key to landscape evolution across passive margins. Earth and Planetary Science Letters, 425, 154-167.

Montgomery. D. R., Buffington, J.M. (1998) Channel processes, classification, and response. in R. J. Naiman and R. E. Bilby (eds.), River Ecology and Management: Lessons from the Pacific Coastal Ecoregion. Springer, New York, NY. Pages 13-42.

Nagendra, R., Reddy, A. N. (2017). Major geologic events of the Cauvery Basin, India and their correlation with global signaturesA review. Journal of Palaeogeography, 6(1), 69-83.

Narula, P.L., Acharyya, S.K., Banerjee, J., 2000. Seismotectonic Atlas of India and its Environs (Geological Survey of India).

Olen, S. M., Bookhagen, B., Strecker, M. R. (2016). Role of climate and vegetation density in modulating denudation rates in the Himalaya. Earth and Planetary Science Letters, 445, 57-67.

Peltzer G., Saucier F. (1996). Present day kinematics of Asia derived from geologic fault rates. Journal of Geophysical Research, 101, 27943-27956.

Pratt, B., Burbank, D. W., Heimsath, A., and Ojha, T., (2002). Impulsive alluviation during early Holocene strengthened monsoons, central Nepal Himalaya. Geology, 2002, 30, 911-914.

Quade, J., Cerling, T. E., Bowman, J. R. (1989). Development of Asian monsoon revealed by marked ecological shift during the latest Miocene in northern Pakistan. Nature, 342(6246), 163.

Rajagopalan G., (1992). Radiocarbon ages of carbonate materials from Gangetic alluvium. In: Singh, I.B. (Ed.), Gangetic plains: Terra Incognita. Army Printing Press, Lucknow, pp. 45-48.

Rajendran, K., Rajendran, C. P. (1998). Characteristics of the 1997 Jabalpur earthquake and their bearing on its mechanism. Current Science, 168-174.

Ramakrishnan, M., Vaidyanadhan, R. (2008). Geological Society of India. Geology of India (Vol. 1). Geological society of India.
Ramesh, R., Subramanian, V. (1988). Temporal, spatial and size variation in the sediment transport in the Krishna River basin, India. Journal of Hydrology, 98(1-2), 53-65.

Ranga, V., Poesen, J., Van Rompaey, A., Mohapatra, S. N., Pani, P. (2016). Detection and analysis of badlands dynamics in the Chambal River Valley (India), during the last 40 (1971-2010) years. Environmental Earth Sciences, 75(3), 183.

Ray, J. S. (2006). Age of the Vindhyan Supergroup: a review of recent findings. Journal of Earth System Science, 115(1), 149-160.

Ray, Y., Srivastava, P. (2010). Widespread aggradation in the mountainous catchment of the Alaknanda Ganga River System: timescales and implications to Hinterland foreland relationships. Quat. Sci. Rev. 29, 2238-2260.

Richards, F. D., Hoggard, M. J., White, N. J. (2016) Cenozoic epeirogeny of the Indian peninsula. Geochemistry Geophysics Geosystems, 17, 1-35, doi:10.1002/2016GC006545.

Rosgen, D.L. (1994). A Classification of Natural Rivers. Catena, 22(3), 169-199. doi:10.1016/0341-8162(94)90001-9.

Roy, N. G., Sinha, R., Gibling, M. R. (2012). Aggradation, incision and interfluve flooding in the Ganga Valley over the past 100,000 years: Testing the influence of monsoonal precipitation. Palaeogeography, Palaeoclimatology, Palaeoecology, 356-357, 38-53.

Sahu, S., Raju, N. J., Saha, D. (2010). Active tectonics and geomorphology in the Sone-Ganga alluvial tract in mid-Ganga Basin, India. Quaternary International, 227(2), 116-126.

Sanyal, P., Sinha, R. (2010). Evolution of the Indian summer monsoon: synthesis of continental records. Geological Society, London, Special Publications, 342(1), 153-183.

Sharma, A., Rajamani, V. (2001). Weathering of charnockites and sediment production in the catchment area of the Cauvery River, southern India. Sedimentary geology, 143(1-2), 169-184.

Shukla, U. K., Srivastava, P., Singh, I. B. (2012). Migration of the Ganga River and development of cliffs in the Varanasi region, India during the late Quaternary: Role of active tectonics. Geomorphology, 171, 101-113.

Singh, A. K., B. Parkash, R. Mohindra, J. V. Thomas, and A. K. Singhvi (2001) Quaternary alluvial fan sedimentation in the Dehradun Valley Piggyback Basin, NW Himalaya: Tectonic and palaeoclimatic implications. Basin Res., 13, 449-471, doi:10.1046/j.0950-091x.2001.00160.x.

Singh, S.K., Rai, S.K., Krishnaswami, S. (2008) Sr and Nd isotopes in river sediments from the Ganga Basin: sediment provenance and spatial variability in physical erosion. J. Geophys. Res. Earth Surf. 113 (doi: 10.1029/2007JF000909).

Sinha, R., Friend, P.F. (1994). River systems and their sediment flux, Indo-Gangetic plains, Northern Bihar, India. Sedimentology 41, 825-845.

Sinha, R., Jain, V. (1998). Flood hazards of north Bihar rivers, IndoGangetic plains. Memoirs-Geological Society of India, 27-52.

Sinha R., Friend P.F., Switsur V.R. (1996). Radiocarbon dating and sedimentation rates in the Holocene alluvial sediments of the northern Bihar plains, India. Geological Magazine, 133 (1), 8590.

Sinha, R., Jain, V., Babu, G. P., Ghosh, S. (2005a). Geomorphic characterization and diversity of the fluvial systems of the Gangetic Plains. Geomorphology, 70(3-4), 207-225.

Sinha, R., Gibling, M.R., Tandon, S.K., Jain, V., Dasgupta, A. S. (2005b) Quaternary stratigraphy and sedimentology of the Kotra section on the Betwa river, Southern Gangetic plains, Uttar Pradesh. Jour. Geological Society of India, 65, 441-450.

Sinha, R., Kettanah, Y., Gibling, M. R., Tandon, S. K., Jain, M., Bhattacharjee, P. S., Dasgupta, A. S., Ghazanfari. P. (2009). Craton-derived alluvium as a major sediment source in the 
Himalayan Foreland Basin of India. Geological Society of America Bulletin, 121(11-12), 1596-1610.

Sinha, R., Mohanta, H., Jain. V., Tandon, S.K. (2017) Geomorphic diversity as a river management tool and its application to the Ganga River, India. River Research and Applications, 33(7), 11561176. DOI: 10.1002/rra.3154.

Sinha, R., Gupta, A., Mishra, K., Tripathi, S., Nepal, S., Wahid, S.M., Swarnkar, S. (2019). Basin-scale hydrology and sediment dynamics of the Kosi River in the Himalayan foreland. Journal of Hydrology, 570, 156-166.

Sonam, Jain, V. (2017). River long profile and stream power analysis to map spatial variability in geomorphic processes along major rivers of peninsular India. Abstract, 9th International Conference on Geomorphology - New Delhi, India - November 6-11, 2017.

Sonam, Jain, V. (2018). Geomorphic effectiveness of a long profile shape and the role of inherent geological controls in the Himalayan hinterland area of the Ganga River basin, India. Geomorphology, 304, 15-29.

Sridhar, A. (2007). Mid-late Holocene hydrological changes in the Mahi River, arid western India. Geomorphology, 88(3-4), 285297.

Srivastava, P., Singh, I.B., Sharma, M., Singhvi, A.K., (2003). Luminescence chronometry and Late Quaternary geomorphic history of the Ganga Plain, India. Palaeogeography, Palaeoclimatology, Palaeoecology 197, 15-41.

Srivastava, V., Mukul, M., Barnes, J.B. (2016). Main Frontal thrust deformation and topographic growth of the Mohand Range, northwest Himalaya. Journal of Structural Geology 93, 131-148.

Subrahmanya, K. R. (1994). Post-Gondwana tectonics of the Indian peninsula. Current Science, 67(7), 527-530.

Subrahmanya, K. R. (1998). Tectono-magmatic evolution of the west coast of India. Gondwana Research, 1(3-4), 319-327.

Tada, R., Zheng, H., Clift, P.D. (2016). Evolution and variability of the Asian monsoon and its potential linkage with uplift of the Himalaya and Tibetan Plateau. Progress in Earth and Planetary Science, 3(1), 3: 4. doi:https://doi.org/10.1186/s40645-016-0080y.

Tandon, S.K., Sinha, R. (2007). Geology of large river systems. Large rivers: geomorphology and management, pp.7-28.

Tandon, S.K., Sareen, B.K., Rao, M.S., Singhvi, A.K., (1997). Aggradation history and luminescence chronology of Late Quaternary semi-arid sequences of the Sabarmati basin, Gujarat, western India. Palaeogeography, Palaeoclimatology, Palaeoecology, 128, 339-357.

Tandon, S. K., Gibling, M. R., Sinha, R., Singh, V., Ghazanfari, P., Dasgupta, A., Jain, M., Jain, V., (2006). Alluvial valleys of the Gangetic Plains, India: causes and timing of incision. In:
Dalrymple, R.D., Leckie, D.A., Tillman, R. (Eds.), Incised Valleys in Time and Space: SEPM Special Publication, 85, pp. 15-35.

Thakur, V. C., Joshi, M., Sahoo, D., Suresh, N., Jayangondapermal, R., Singh, A. (2014). Partitioning of convergence in Northwest Sub-Himalaya: estimation of late Quaternary uplift and convergence rates across the Kangra reentrant, North India. International Journal of Earth Sciences, 103(4), 1037-1056.

Thokchom, S., Bhattacharya, F., Durga Prasad, A., Dogra, N. N., Rastogi, B. K. (2017). Paleoenvironmental implications and drainage adjustment in the middle reaches of the Sabarmati river, Gujarat: Implications towards hydrological variability. Quaternary International, 454, 1-14.

Tripathi, J. K., Bock, B., Rajamani, V., Eisenhauer, A. (2004). Is River Ghaggar, Saraswati? Geochemical constraints. Current Science, 87, 1141-1145.

Valdiya, K.S. (1998). Dynamic Himalaya. Universities Press (India) Limited, 178 pp.

Valdiya, K.S., 2003. Reactivation of Himalayan frontal fault: implications. Current Science, 85, 1031-1040.

Valdiya, K. S. (2015). The making of India: geodynamic evolution. Springer, Switzerland.

Waghmare, S. Y., Carlo, L., Gawali, P. B., Patil, A. G. (2008). Geomagnetic investigation in the seismoactive area of NarmadaSon Lineament, Central India, 12(1), 1-10.

Wasson, R.J. (2003) A sediment budget for the Ganga-Brahmaputra catchment. Curr. Sci., 84, 1041-1047.

Wells N.A., Dorr J.N. (1987). Shifting of the Kosi river, northern India. Geology, 15, 204-207.

Wesnousky S.G., Kumar S., Mohindra R., Thakur V.C., (1999). Uplift and convergence along the Himalayan Frontal Thrust of India. Tectonics, 18 (6), 967-976.

West, W. D. (1962). The line of the Narmada and Son valleys. Current Science, 31, 143-144.

Williams, M.A.J., Pal, J.N., Jaiswal, M., Singhvi, A.K. (2006). River response to Quaternary climatic fluctuations: evidence from the Son and Belan valleys, north-central India. Quaternary Science Reviews 25, 2619-2631.

WRIS Report (2014). River basin atlas of India. India-Govt. of India, Ministry of Water Resources-Central Water Commission and Indian Space Research Organisation (Unpublished report).

Yin, A., Harrison, T. M. (2000). Geologic evolution of the HimalayanTibetan orogen. Annual Review of Earth and Planetary Sciences, 28(1), 211-280.

Zhisheng, A., Kutzbach, J. E., Prell, W. L., Porter, S. C. (2001). Evolution of Asian monsoons and phased uplift of the HimalayaTibetan plateau since Late Miocene times. nature, 411(6833), 62. 


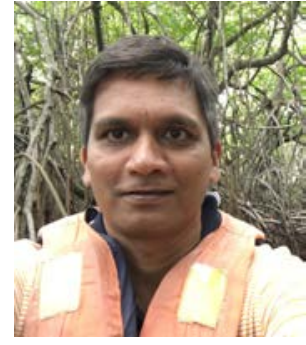

Vikrant Jain is Professor in Earth Sciences Discipline, IIT Gandhinagar, India. He is a geomorphologist and his broad research interests encompassing River Science and Earth Surface Processes. His current research focus is (1) to use quantitative approaches for understanding cause-effect relationships in Earth Surface Processes at different spatio-temporal scales and (2) to develop geomorphic tools for sustainable stream management.

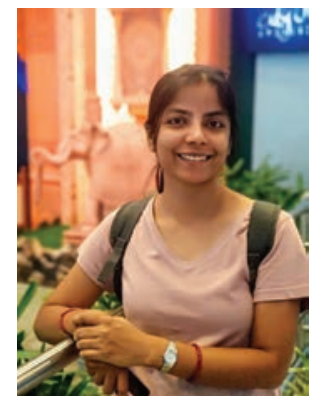

Sonam has a PhD in Earth Sciences from Indian Institute of Technology Gandhinagar (IITGN). She is currently a Research Associate at IIT Gandhinagar. She is mainly engaged in the field of river long profile evolution, geological controls on river morpho-dynamics and application of river morphological analysis for river management.

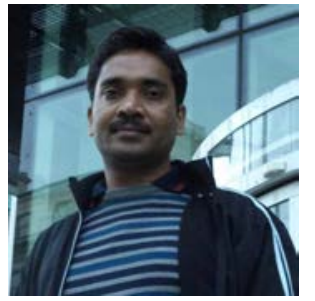

Ajit Singh is post-doctoral fellow in Earth Sciences Discipline, IIT Gandhinagar. He attained PhD in fluvial sedimentology from Department of Civil Engineering, IIT Kanpur. He has also worked at Imperial College London - as a Post-Doctoral Research Associate in the Department of Earth Sciences and Engineering. His research interest includes application of sedimentology, geochronology and geochemistry to understand sediment provenance, alluvial systems and fluvial morpho-dynamics, and their controls across spatial and temporal scales. 